University of Nebraska - Lincoln

DigitalCommons@University of Nebraska - Lincoln

Papers in the Earth and Atmospheric Sciences Earth and Atmospheric Sciences, Department

2003

\title{
Late Albian adaptive radiation in the calcareous nannofossil genus Eiffellithus
}

David K. Watkins

University of Nebraska-Lincoln, dwatkins1@unl.edu

James A. Bergen

BP America, Inc.

Follow this and additional works at: https://digitalcommons.unl.edu/geosciencefacpub

Part of the Earth Sciences Commons

Watkins, David K. and Bergen, James A., "Late Albian adaptive radiation in the calcareous nannofossil genus Eiffellithus" (2003). Papers in the Earth and Atmospheric Sciences. 165.

https://digitalcommons.unl.edu/geosciencefacpub/165

This Article is brought to you for free and open access by the Earth and Atmospheric Sciences, Department of at DigitalCommons@University of Nebraska - Lincoln. It has been accepted for inclusion in Papers in the Earth and Atmospheric Sciences by an authorized administrator of DigitalCommons@University of Nebraska - Lincoln. 


\title{
Late Albian adaptive radiation in the calcareous nannofossil genus Eiffellithus
}

\author{
David K. Watkins ${ }^{1}$ and James A. Bergen ${ }^{2}$ \\ ${ }^{1}$ Department of Geosciences, University of Nebraska, Lincoln, Nebraska 68588-0340 \\ email: dwatkins1@unl.edu \\ ${ }^{2}$ BP America, Inc., 501 Westlake Park Blvd., Houston, Texas 77079
}

\begin{abstract}
Well preserved nannofossil assemblages in upper Albian and lower Cenomanian hemipelagic sections from Ocean Drilling Program (ODP) Leg 171B preserve a record of the early history and adaptive radiation of the genus Eiffellithus. Seven distinct taxa are recognized and differentiated, with one previously named taxon (E. monechiae) emended and four new species described: $E$. praestigium, E. vonsalisiae, E. equibiramus, and E. parvus. Sample census data indicate that most species evolved, rose to dominance, and then rapidly declined to extinction, to be replaced by other members of the genus. Newly evolved species tended to remain at low abundance levels until a significant disruption in the pelagic realm resulted in the precipitous decline of the dominant species. This decline provided open niche space in the pelagic realm into which the new species could rapidly rise to dominance. These major disruptions correspond to significant changes or shifts in the sedimentological and carbon isotopic records associated with the late Albian Oceanic Anoxic Event (OAE-1d), suggesting that major changes in the strength of deep mixing and the structure of the surface water mass drove the early adaptive radiation of Eiffellithus.
\end{abstract}

\section{INTRODUCTION}

The first appearance datum (FAD) of Eiffellithus turriseiffelii was one of the first calcareous nannofossil biostratigraphic horizons recognized by paleontologists in the Cretaceous. Stradner (1964) used the presence of E. turriseiffelii (as Rhabdolithus turriseiffelii) without Micula decussata (as Micula staurophora) to define the Cenomanian "turriseiffelii association". Thierstein (1971) correctly placed this datum in the upper Albian, and later used it as a biohorizon in the first complete Cretaceous nannofossil biostratigraphic scheme that was calibrated to stratotypes (Thierstein 1976). This datum was incorporated in all subsequent Cretaceous zonation schemes (e.g., Manivit et al. 1977, Sissingh 1977, Perch-Nielsen 1985).

The widespread confidence in the use of the FAD of E. turriseiffelii is well founded. In many respects, this species is an ideal index fossil. It is a large nannofossil whose characteristic thin outer rim, large central area filled with blocky elements, and distinctive stem render it prominent and easily recognizable. The construction of this robust nannofossil is such that it tenaciously resists diagenesis, making it one of the last species to be removed by dissolution (Hill 1975; Thierstein 1980). The species had a cosmopolitan distribution that persisted throughout its age range. It is a common to abundant component of Upper Cretaceous assemblages generally comprising at least $1 \%$ of these assemblages, and often more than $10 \%$. Finally, once the character of the species stabilized during the late Albian and early Cenomanian, E. turriseiffelii remained remarkably uniform in morphology, size, and structural detail for the rest of the Late Cretaceous.

This quintessential Late Cretaceous species was the product of a relatively short $(<3$ m.y.) burst of speciation and extinction within the newly evolved genus Eiffellithus during the late Albian. This history is well expressed in the relatively complete stratigraphic successions of hemipelagic sedimentary rock in
Ocean Drilling Program (ODP) Holes 1050C and 1052E from the western North Atlantic. Examination of these records reveals a pattern of adaptive radiation that features relatively rapid speciation coupled with significant shifts in species dominance.

\section{LOCALITY}

The Blake Nose is a topographic salient on the eastern margin of the Blake Plateau approximately 500km east of Jacksonville, Florida (text-fig. 1). Blake Nose is a gentle ramp reaching from the Blake Plateau on the west (ca. 1000m deep) down to the edge of the Blake Escarpment to the east (ca. 3000m deep). The structure is draped by mid-Cretaceous through Eocene pelagic sedimentary rocks, with thick sequences of Albian and Cenomanian pelagic carbonates. ODP Leg 171B drilled these pelagic carbonates in two holes that were used in this study: 1050C and 1052E.

Hole 1050C is located on the deep end of the Blake Nose, in about $2300 \mathrm{~m}$ of water. The Albian-Cenomanian spans the interval from 501 to 605 meters below sea floor (mbsf), as represented by Cores 1050C-21R through $-31 \mathrm{R}$. The lithologic sequence is described in Norris et al. (1998), who designated this interval as lithologic Unit VI and recognized two subunits. The upper 53m (lithologic Subunit VIa; 501-553.9 mbsf) consists of light greenish gray nannofossil chalk and limestone interbedded with medium greenish gray nannofossil claystone. Core recovery in this subunit was $72.4 \%$. The lower $52 \mathrm{~m}$ (lithologic Subunit VIb; 553.9-606.0 mbsf) consists of olive gray claystone alternating with laminated dark claystone. Core recovery for this subunit was excellent at $99.6 \%$. According to the biostratigraphy of Bellier et al. (2001), the Albian-Cenomanian boundary (553.59 to $552.08 \mathrm{mbsf}$ ) approximately corresponds to the gradational subunit boundary (553.9 mbsf). Calcareous nannofossils are common to abundant throughout this entire interval and are generally well preserved. 


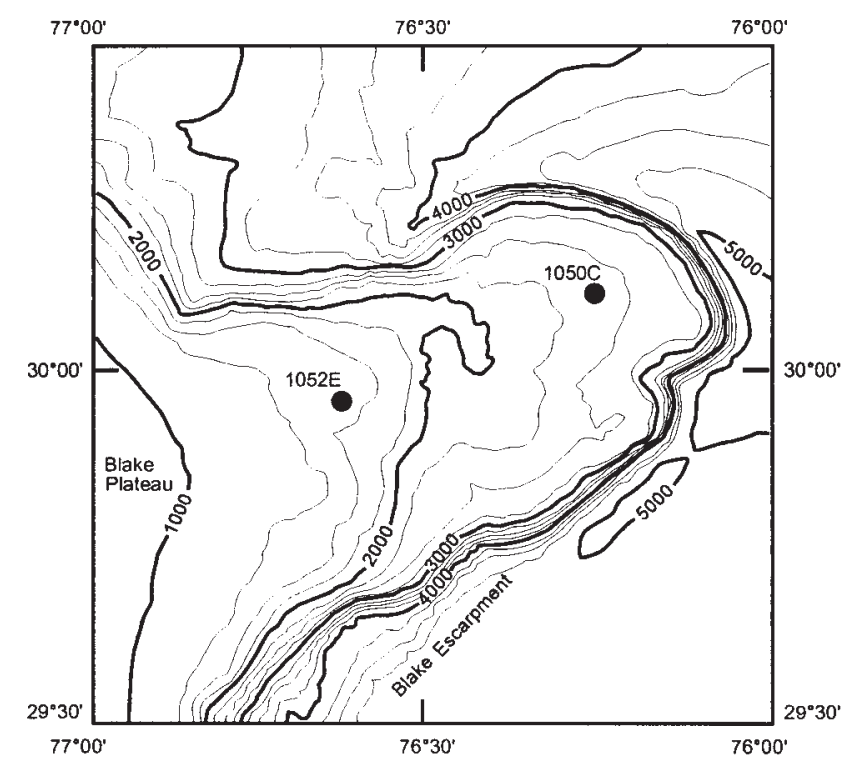

TEXT-FIGURE 1

Locality map of ODP Sites 1050 and 1052.

Hole $1052 \mathrm{E}$ is located near the top of Blake Nose, at approximately $1350 \mathrm{~m}$ water depth. Cores $1052 \mathrm{E}-36 \mathrm{R}$ through $58 \mathrm{R}$ contain $210.3 \mathrm{~m}$ (474.5 to $684.8 \mathrm{mbsf})$ of upper Albian and Cenomanian hemipelagic sedimentary rocks. Norris et al. (1998) recognized three lithologic subunits (Subunits Va, Vb, and $\mathrm{Vc}$ ) in this sequence, reflecting changes in the dominant lithology. The upper part (subunit Va; 477.4-511.8 mbsf) consists of dark olive silty claystone and calcareous claystone. The silty claystones are generally enriched with foraminifers and quartz silt. Core recovery in this interval was approximately 93\%. The middle of the unit (Subunit Vb; 511.34-633.50 mbsf) is composed of rhythmically alternating dark calcareous claystone and laminated claystone ("black shale") with minor light-colored limestone beds. There is a general increase in silt-size siliciclastic grains downward through this subunit. Core recovery for this subunit was about $79 \%$. The lower $51.3 \mathrm{~m}$ (Subunit Vc; 633.2-684.8 mbsf) consists of dark olive gray sandy siltstone with interbeds of quartz and bioclast-rich grainstones. Sand content generally increases downward, as does the thickness of the grainstone intervals. Calcareous nannofossils are generally abundant and well preserved in the fine-grained rock throughout this sequence, with some samples from each subunit exhibiting truly splendid preservation.

\section{METHODS}

A set of 50 samples from $1050 \mathrm{C}$ and 63 samples from $1052 \mathrm{E}$ were selected for this study. These were chosen from a larger set of samples based on their superior calcareous nannofossil abundance and preservation as well as their stratigraphic distribution. Smear slides were prepared from these samples using a double suspension method. In this method, a sediment-water suspension is fully dried on a cover glass, and then re-suspended in just enough water to form a liquid slurry. This slurry is smeared over the cover slide and rapidly dried. This double suspension method permits a thorough dispersion of the material while preventing any size (or shape) fractionation on the slide. Multiple population counts from single test slides indicated no distributional bias due to nannofossil size or shape (confidence interval $>99.99 \%$ ).
Counts of 456 specimens per sample were conducted to determine the percentage of all eiffellithids in the population of nannofossils to document the rise to prominence of the genus during its early evolution. This census number was chosen because it insures that the maximized second standard deviation of the percentage estimate is within $5 \%$ of the actual proportion at the $95 \%$ confidence interval (Chang 1967). These counts were used to ascertain the proportion of each eiffellithid species relative to the total population of eiffellithids. Data for Hole 1050C and 1052E are presented in Tables 1 and 2, respectively. Census counts, taxonomic observations, and biometric measurements were made using a Zeiss Photoscope II at $\times 1250$ magnification.

Rock samples and smear slides are housed within the collections of the ODP Micropaleontological Reference Center at the University of Nebraska State Museum (UNSM). Holotype and paratype materials (i.e., smearslides and photographic negatives) and topotype samples are housed in the Invertebrate Paleontology Type Collection at the UNSM.

\section{Age Model}

Wilson and Norris (2001) used the cyclically-varying, midCretaceous lithologic sequence in Hole 1052E (as recorded in the neutron porosity downhole log) to construct an orbital cyclostratigraphy supported by calcareous nannofossil and planktonic foraminifer biostratigraphy. The chronology used in the present paper is essentially the same as theirs with two modifications. Wilson and Norris (2001) placed the AlbianCenomanian boundary in Hole 1052E at approximately 507 mbsf based on planktonic foraminiferal dating in Norris et al. (1998). A subsequent revision of the foraminiferal biostratigraphy (Bellier et al. 2001) suggests the boundary lies at approximately $480 \mathrm{mbsf}$, based on the FAD of the planktonic foraminifer Rotalipora globotruncanoides. This revised placement is adopted for the present age model (text-figure 2). In addition, the age model was extended higher into the lower Cenomanian based on correlation of Holes 1050C and 1052E by cyclostratigraphy and nannofossil biostratigraphy. This age model encompasses approximately 3 my. (98.5-101.5 Ma).

\section{Taxonomic framework}

The genus Eiffellithus arose in the late Albian from the species Vekshinella angusta (Stover 1966) Verbeek 1977 by the invention of a novel construction that includes a distinctive, thin outer rim of inclined, imbricated elements, an inner rim of broad, plate-like or blocky elements that fill much of the central area, and a cross that spans the center of the central area. Neocomian species that have been placed into the genus have no phylogenetic link with the Eiffellithus that arose in the late Albian and Late Cretaceous. Varol and Girgis (1994) reassigned these Neocomian species to the genus Rothia. In a similar manner, two phylogenetically-unrelated taxa from the upper Albian and lower Cenomanian have been placed into the genus: Eiffellithus paragogus Gartner 1993 (=Staurolithites glabra (Jeremiah 1996) Burnett 1998) and Eiffellithus? hancockii Burnett 1998. Neither of these are considered to be a true Eiffellithus (as discussed in Systematic Paleontology section) and are not included in the subsequent discussion.

Early detailed studies of upper Albian calcareous nannofossil assemblages revealed considerable variation in the lineage that gave rise to E. turriseiffelii. Much of this early work focused on the angle subtended between the principal axes of the elliptical rim and the arms of the cross that support the central stem. Hill (1976) illustrated specimens with arms that lay sub-parallel to 
the principle axes of the coccolith. These resembled the Turonian-Campanian Eiffellithus eximius (Stover 1966) Perch-Nielsen 1968 closely enough that Hill (1976) used that name for these upper Albian forms. Verbeek (1977) illustrated the progressive rotation of the cross arms relative to the principal axis of the ellipse through a series of samples from the upper Albian at El Kef, Tunisia. The earliest forms, which Verbeek (1977) equated with Vekshinella angusta, were characterized by angles of less than $20^{\circ}$ between cross arms and principle axes. Later forms, equated with Eiffellithus turriseiffelii, were characterized by larger angles, gradually increasing to the $45^{\circ}$ typical of E. turriseiffelii. These two studies established clearly that there was more than one distinct form in the genus Eiffellithus during the late Albian.

Subdivision of the eiffellithids from the upper Albian and Cenomanian was attempted first by Perch-Nielsen (1979), who recognized six morphotypes. Two of these morphotypes $(E$. turriseiffelii (s.s.) and E. collis) were formal taxa, while four were informal, unnamed forms ("E. sp. 1", " $E$. sp. 2", " $E$. sp. 3", and "E. turriseiffelii A"). No descriptions were given for these morphotypes, although line drawings and a chart of morphological features yield some ideas as to the nature of these forms. The informal "E. turriseiffelii A" appears to differ from E. turriseiffelii (s.s.) by its more rounded shape, distal arm tip morphology (blunt in the former while pointed in the latter), and central area plate thickness (thin in the former, thick in the latter). The informal " $E$. sp. 2" of Perch-Nielsen (1979, 1985) appears to be characterized by a symmetrical cross that is slightly rotated from the diagonal position. No size information is available for this form. Light micrographs of " $E$. sp. 1" and "E. sp. 3" were published (Perch-Nielsen 1985, figs. 5-6 and $7-8$, respectively) providing photographic images as well as size data. Both forms appear to be medium eiffellithids with symmetrical crosses that correspond closely with the major and minor axes of the ellipse.

Hill and Bralower $(1985,1987)$ noted the similarity of some of the Albian morphotypes of Perch-Nielsen $(1979,1985)$ with the Turonian-Campanian Eiffellithus eximius and proposed that they were conspecific. Crux (1991) disagreed with this view, based on biostratigraphic and morphological grounds, and named the Albian morphotype E. monechiae. He noted that $E$. monechiae was restricted to the upper Albian and lowermost Cenomanian, while E. eximius was restricted to the Turonian through Campanian. The two morphotypes could be differentiated by a narrower cycle of block elements in the central area of E. monechiae as compared to E. eximius. Crux (1991) used the name $E$. monechiae for all upper Albian forms whose central cross is aligned within $20^{\circ}$ of the major axes of the ellipse.

The excellent preservation of nannofossils that characterizes much of the Albian from Blake Nose has made it possible to distinguish a number of different species within this highly variable group. Morphological similarities and biostratigraphical relationships suggest that two distinct lineages of eiffellithids arose from the early forms (E. monechiae and $E$. praestigium) during the late Albian (text-fig. 3). It appears that both lineages split from E. praestigium.

The first lineage includes forms assigned to E. monechiae (as defined by Crux, 1991) and E. turriseiffelii. The well-preserved assemblages of Leg 171B demonstrate that four distinct species can be recognized in this lineage. Three of these taxa overlap with the concept of E. monechiae as designated by Crux (1991).

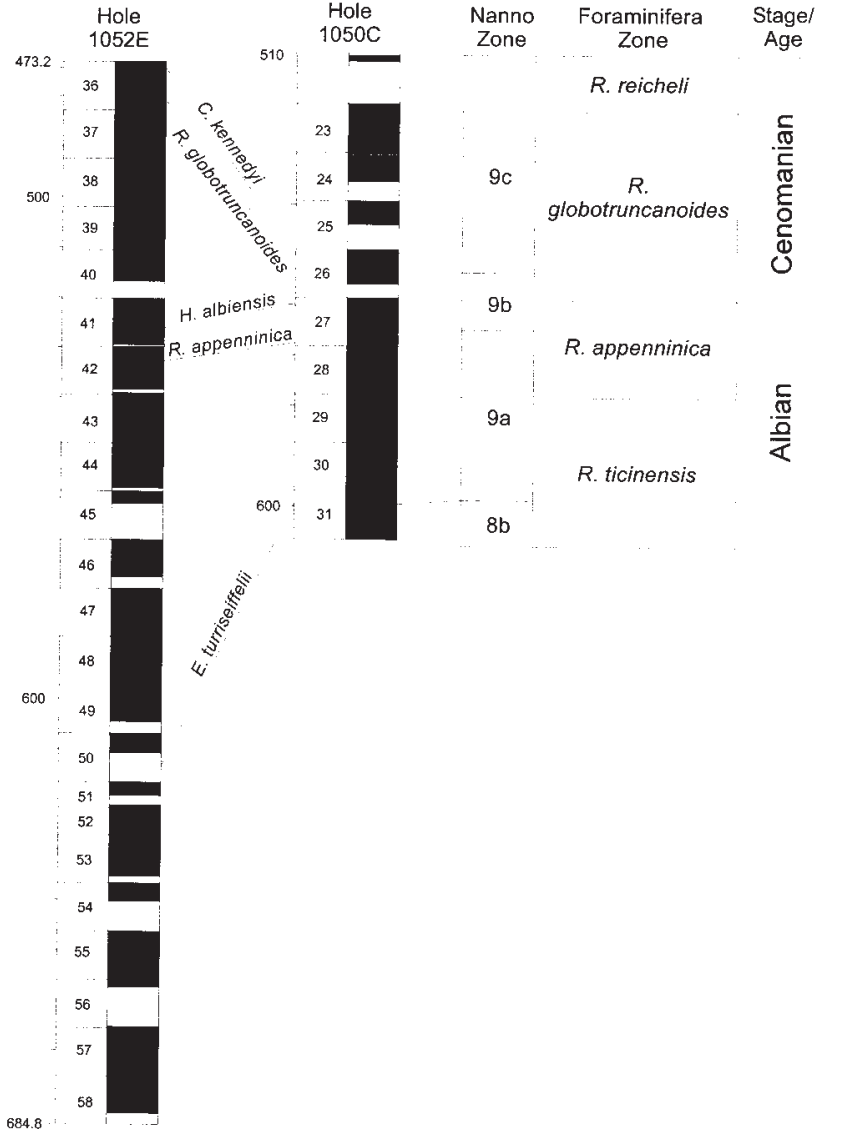

TEXT-FIGURE 2

Biostratigraphy of the study interval from ODP Holes 1050C and 1052E. For each hole, from left to right, are the depth in meters below sea floor, core number, and core recovery (with black indicating recovered core and white indicating empty core barrel). The nannofossil zonation is based on unpublished data of Watkins and is correlated to the zones of Perch-Nielsen (1985). The foraminiferal zonation is from Bellier et al (2001).

The earliest form, corresponding to the holotype of $E$. monechiae, is designated E. monechiae (s.s.; as emended herein). In this form, the arms of the cross intersect with the principal axes of the coccolith ellipse for most or all of its length. These arms appear to be sub-parallel with the ellipse axes regardless of their orientation with the crossed polarizers. Each arm consists of two sets of elements that bifurcate distally and terminate in a distinctly clavate tip. The length of the coccolith varies from about 5.8 to $7.5 \mu \mathrm{m}$ (text-fig. 4). This species appears to have evolved directly from Vekshinella angusta, as suggested by Verbeek (1977), as transitional forms between these species are common in the lower $10 \mathrm{~m}$ of the study interval in Hole 1052E.

This lineage evolved by rotation of the cross relative to the principal axes of the coccolith ellipse, the transformation of the cross arm tips, and an increase in the overall size of the coccolith. Verbeek (1977) documented the progressive rotation of the cross in the early part of the range of the eiffellithids, and that rotation is also clear in the Leg $171 \mathrm{~B}$ material. The next species in this lineage, E. praestigium, is characterized by a cross whose arms do not intersect the principal axes of the el- 




TEXT-FIGURE 3

Proposed calibrated range chart.

lipse except at the center of the ellipse. This corresponds to a rotation of approximately $10-20^{\circ}$ from the principal axes. This orientation of the cross results in a "trick" when viewed with cross polarized light, in which the extinction image of the cross alternatively appears to be sub-parallel or sub-diagonal to the principal axes. The arms retained the bifurcate, clavate morphology of E. monechiae, although this feature is best developed early in the range of E. praestigium. The length of the coccolith varies between 5.3 to $7.3 \mu \mathrm{m}$, similar to its ancestor $E$. monechiae (text-fig. 4).

Progressive rotation of the cross through time gave rise to $E$. vonsalisiae. In this taxon, the orientation of the cross to the principal axes is approximately $20-35^{\circ}$ (Plate 2, figs. 7-9). At this angle, the praestigium "trick" no longer works, as there is no orientation at which the arms appear to be sub-parallel to the major axis of the ellipse. The two sets of elements that comprise each arm are fused distally, as opposed to the distinctive bifurcate morphology of earlier forms, and the tips are fused and tapered (as opposed to clavate). The arms retain the asymmetry of their length, with the arms closest to the major axes being longer than the pair near the minor axis. In addition, E. vonsalisiae exhibits a significantly greater size variation than its ancestor species, with coccolith length ranging from about 6.5 to $9.0 \mu \mathrm{m}$ (text-fig. 4).

The rotation of the cross was completed when the arms came to lie diagonally (at approximately $45^{\circ}$ to the principal axes) in $E$. turriseiffelii (Plate 2, figs.10-12). The asymmetry of the arm length disappeared, as all of the arms became equal in length and prominence. The arms taper to symmetrical tips, effectively obscuring their bipartite origins. The size range was limited initially to approximately 5.5 to $8.0 \mu \mathrm{m}$ in length, but subsequently increased in variability by the addition of larger coccoliths $(>8.5 \mu \mathrm{m})$, as is illustrated in text-figure 5 .

A second lineage splits from the original lineage at about 101.4 Ma. This lineage is characterized by relatively compact eiffellithids (text-fig. 4) with nearly closed central areas. The first species to evolve in this lineage, E. equibiramus, is characterized by a symmetrical, diagonal cross with each arm of the cross made of two, subequal, rectangular sets of elements (Plate 1, figs. 1-6, Plate 4, fig. 4). Transitional forms between $E$. equibiramus and E. praestigium suggest that the former evolved from the latter by rotation and simultaneous broadening of the arms of the cross. This cross effectively covers the small opening in the central area, as only a small indication of the opening is visible in even pristinely preserved specimens. A second species, E. parvus (Plate3, Figs. 1-6, Plate 4, Figs. 5-6), arose from this lineage at about 100.7 Ma. Transitional forms between $E$. equibiramus and E. parvus, and their biostratigraphic relationship, suggests that the latter evolved from the former by reduction of the arms from rectangular to trapezohedral and by an increase in the eccentricity of the coccolith. The final species of this lineage is $E$. collis, which apparently evolved from $E$. parvus by a significant increase in size and elongation of the trapezohedral cross arms (Plate 3, figs. 7-8).

Comparisons of these newly named forms with the species concepts of previous authors are not simple, nor even always possible. The species E. monechiae s.s. (as herein emended) is clearly part of the complex designated by the same name by Crux (1991). Illustrations in Crux (1991) and the micrographs referenced therein indicate that the original concept of $E$. monechiae encompassed forms that are herein taxonomically split into E. monechiae (s.s.), E. praestigium, and E. vonsalisiae. In a similar fashion, the thorough micrographic documentation of Hill (1976) and Hill and Bralower (1987) demonstrate that the forms they assigned to E. eximius included E. monechiae, E. praestigium, and E. vonsalisiae. The informal morphotypes designated by Perch-Nielsen $(1979,1985)$ are more difficult to relate directly to these new species, as discussed in the Systematic Paleontology section. It seems clear from the micrographic evidence, however, that her " $E$. sp. 1" and "E. sp. 3" are E. vonsalisiae and E. monechiae (s.s.), respectively.

\section{Biostratigraphic distribution}

The stratigraphic sections drilled during Leg 171B did not penetrate deep enough to recover the FAD of E. monechiae and $E$. praestigium. The relatively high abundance of Vekshinella angusta and forms transitional between $V$. angusta and $E$. monechiae strongly suggest, in light of records from other sections, that the base of the genus Eiffellithus was just below the total depth of Hole 1052E. Regardless of the truth of this assertion, these sections cannot be used to precisely date these two biohorizons. The FAD of E. monechiae, which is equivalent to the FAD of the genus Eiffellithus (s.s.), has been used as a biostratigraphic horizon in Bralower et al. (1993), Bralower et al. (1997), and Bown, et al. (1999).

Based on the Leg 171B material, the first form to appear with a cross approaching the symmetrical diagonal position was $E$. 

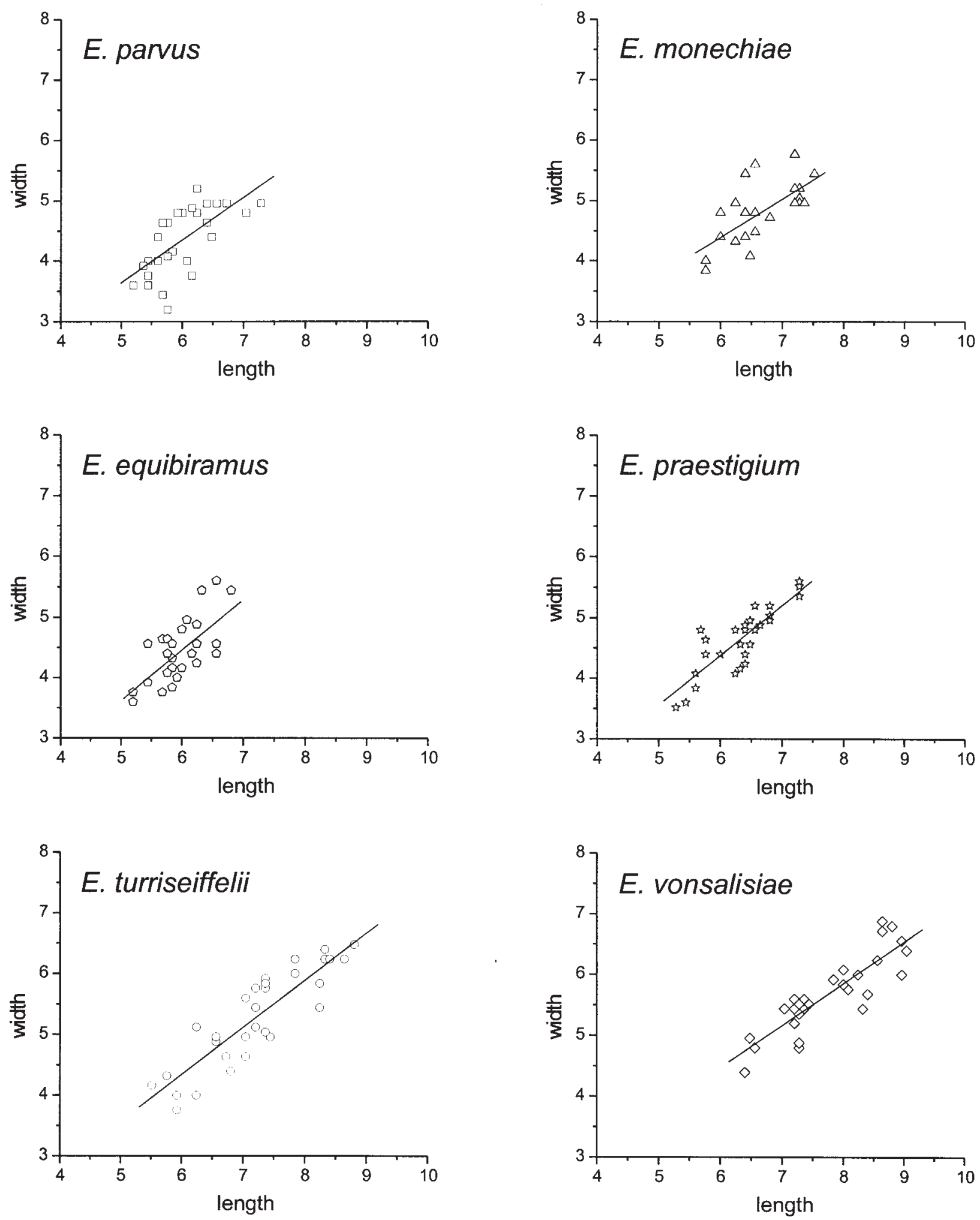

TEXT-FIGURE 4

Length and width measurements for representative samples of six eiffellithid species, illustrating the size range and variability. All measurements are in micrometers, with a measurement error of approximately $0.2 \mu \mathrm{m}$. Measurements for E. equibiramus, E. parvus, and E. vonsalisiae are from Sample 1052E-49R-5, 7-10cm. Measurements for E. praestigium and E. monechiae are from Sample 1052E-57R-3, 54-57cm. Measurements for E. turriseiffelii are from Sample 1050C-46R-5, 38-39cm. 

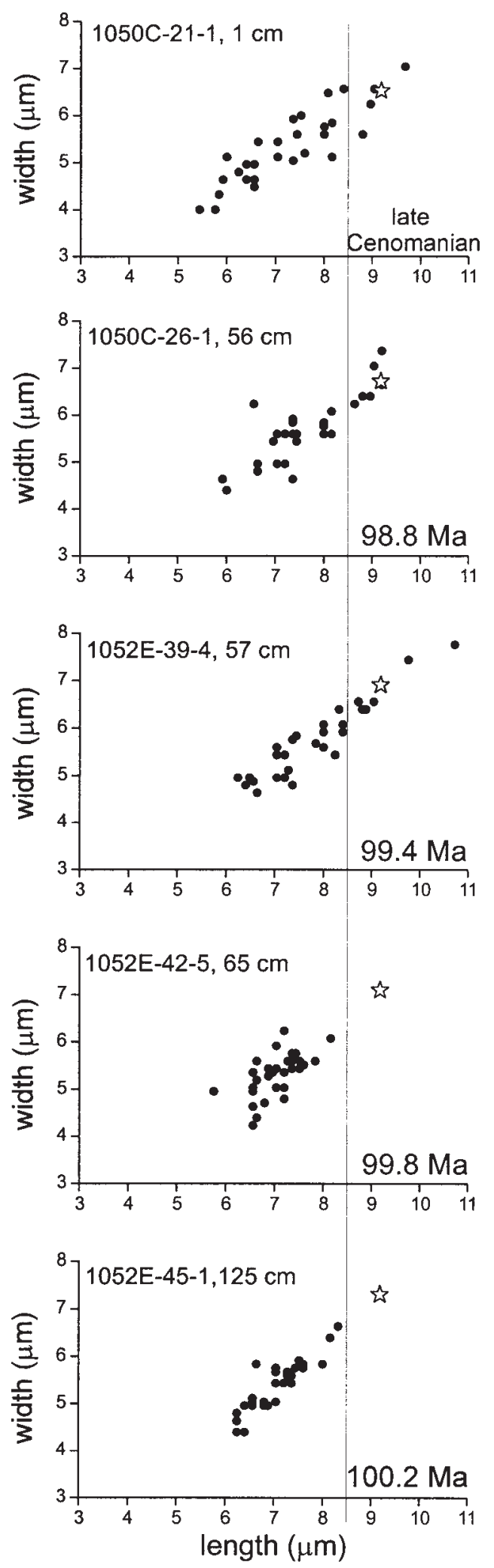

TEXT-FIGURE 5

Length vs. width relationship for five samples of E. turriseiffelii. Note that the samples from older populations (100.2 and $99.8 \mathrm{Ma}$ ) contain only forms smaller than $8.5 \mu \mathrm{m}$ in length, while later ones contain the larger morphotypes. The star in each graph indicates the size of the holotype for E. turriseiffelii. equibiramus at approximately 101.4 Ma. The FAD of $E$. vonsalisiae occurred shortly afterwards, at about $101.1 \mathrm{Ma}$, although the gradational nature of its evolution from $E$. praestigium makes this event difficult to identify confidently. This problem would certainly be exacerbated in poorly preserved material. The first occurrence of E. parvus (with clearly rectangular outlines of the stem bases, as is typical) was at approximately $100.7 \mathrm{Ma}$. The FAD of the important biostratigraphic indicator species E. turriseiffelii occurred at about 100.5 Ma. Specimens of E. turriseiffelii remained less than $8 \mu \mathrm{m}$ in length for approximately the first $0.6 \mathrm{Ma}$ of their range, as the first specimens $>8 \mu \mathrm{m}$ appeared at about $99.9 \mathrm{Ma}$.

Three species go extinct near the Albian/Cenomanian boundary. Both E. vonsalisiae and E. equibiramus have last appearance datums (LAD) below the boundary. The exact positions of these two events are difficult to place confidently because both species become rare in the uppermost part of their ranges. The LAD of E. parvus is just above the Albian-Cenomanian boundary, yielding an estimate of approximately 98.9 Ma for its extinction. Only E. turriseiffelii and (rare) E. collis persist significantly above the boundary.

There are eleven first or last appearance datums of eiffellithids within the $3.5 \mathrm{~m}$.y. time frame of this study (text-fig. 3). Graphic correlation (text-fig. 6) indicates that the order and approximate stratigraphic spacing of these events is consistent within the overlapping parts of the sections at Sites 1050 and 1052. In addition, the line of correlation indicated by the eiffellithid datums is compatible with the independent evidence of the planktonic foraminifers in the upper part of the sequence. The well-behaved nature of this graphic correlation is not unexpected, considering that the two sites are only $40 \mathrm{~km}$ apart. It does, however, indicate the biostratigraphic replicability of the proposed evolutionary scheme in two stratigraphic sections with markedly different histories of sediment accumulation.

This suggests the possibility of as many as 11 eiffellithid datums in this 3.5 m.y. interval. It is probable, however, that only some of these biostratigraphic horizons will prove to be of wide utility. This will certainly be true in sections with poor preservation, as the distinction between some species (e.g., $E$. praestigium and $E$. vonsalisiae) could be rendered difficult or impossible by overgrowth of the central cross structure.

Consideration of the abundance patterns also suggests that some biostratigraphic horizons will be more obvious than others. All biostratigraphic indicators were not created equal. The FAD of E. turriseiffelii will continue to be used as a biostratigraphic marker because it is a large, distinctive form that is common from its inception. In a similar manner, the FAD and LAD of $E$. parvus may be useful, as this distinctive (albeit smallish) form is relatively abundant from its inception to its extinction. In addition, its LAD is at or slightly above the Albian-Cenomanian boundary (as defined by the FAD of Rotalipora globotruncanoides). The reliability of any of these biostratigraphic horizons will have to be tested at other, well-dated sections before their utility can be assessed.

\section{Abundance distribution}

The eiffellithids exhibited an interesting pattern of abundance variations accompanying species evolution in the late Albian (text-fig. 7). Eiffellithus monechiae was the dominant form during the first part of the sequence, an interval equivalent to at least $200 \mathrm{k} . \mathrm{y}$. At about $101.3 \mathrm{Ma}$, there was a dominance rever- 
sal as E. praestigium reached abundances in excess of $50 \%$. This dominance continued for about 700 k.y. (101.3 to 100.8 $\mathrm{Ma})$, during which time the abundance of E. monechiae gradually decreased to $<10 \%$. Eiffellithus equibiramus and E. vonsalisiae appeared during this interval, but remained at low abundance levels $(<15 \%)$. Between 100.8 and 100.7 Ma there was a second dominance change as the abundance of $E$. praestigium dropped to low levels $(<12 \%)$ while $E$. equibiramus and E. vonsalisiae increased to more than $30 \%$ each. From about 100.7 to 100.2 Ma, E. equibiramus and (secondarily) E. vonsalisiae were the most abundant eiffellithids, while E. praestigium continued to decline in abundance until its extinction (ca. 100.2 Ma). These two dominant species were joined by E. parvus (at $100.7 \mathrm{Ma}$ ) and E. turriseiffelii (at 100.5 $\mathrm{Ma})$, both of whose abundance levels gradually rose to about $25 \%$. At about 100.2 Ma, E. turriseiffelii exhibited a marked increase in abundance to levels of $40-50 \%$. It remained at these levels until about 99.1 Ma. During the interval from 100.2 Ma to $99.1 \mathrm{Ma}$, the abundance of both E. equibiramus and $E$. vonsalisiae gradually declined to low levels $(<10 \%)$, while that of E. parvus slightly increased to 30-40\%. Eiffellithus collis appeared at $100.3 \mathrm{Ma}$ and persisted through the remainder of the sequence, but never attained abundance levels above about $10 \%$.

A final change in dominance was associated with the Albian-Cenomanian boundary. Abundance levels of E. parvus decreased from $30-40 \%$ to less than $20 \%$ just prior to the boundary, and disappeared just above the boundary. The decrease in E. parvus was accompanied by a similarly rapid increase in E. turriseiffelii. The small morphotype of $E$. turriseiffelii increased in abundance slightly (from $40-50 \%$ to about 50-60\%). The large morphotype of E. turriseiffelii exhibited a much more substantial increase in abundance, with average values changing from $<15 \%$ in the uppermost Albian to more than $30 \%$ in the lowermost Cenomanian of Sites 1050 and 1052 .

The genus Eiffellithus became a numerically more important component of the nannofossil assemblages during the study interval (text-fig. 8). During the early part of the interval (prior to 100.0 Ma), it was rare for the eiffellithids to exceed $3.4 \%$ of the total nannofossil assemblage. During the later part of the interval (after 99.0 Ma), no assemblage had fewer than $3.4 \%$ eiffellithids. This increase can be approximated by a linear relation, derived from regression, with a high correlation $(\mathrm{r}=0.715$, $\mathrm{p}<0.0001)$. This linear relationship indicates a rate of increase of about $1.5 \%$ per m.y. This relationship was not the result of variations in species richness, as analysis documents no statistically significant correlation $(\mathrm{r}=-0.186, \mathrm{p}=0.107)$. The trend towards increasing eiffellithids in the assemblages through time correlates significantly only with the increase in the relative abundance of E. turriseiffelii in time. The correlation between total eiffellithids and E. turriseiffelii is statistically significant ( $\mathrm{r}$ $=0.630, \mathrm{p}<0.0001$ ), although it is lower than the correlation of either total eiffellithids or E. turriseiffelii with age. This suggests that there is not a direct causal relationship between the increase in total eiffellithids in the assemblages and the increasing dominance of E. turriseiffelii among its sister species, but that they both increased in response to some other environmental factor.

\section{Pattern of adaptive radiation}

Examination of the abundance distributions (text-fig. 7) indicates a similarity between the abundance histories of the spe-

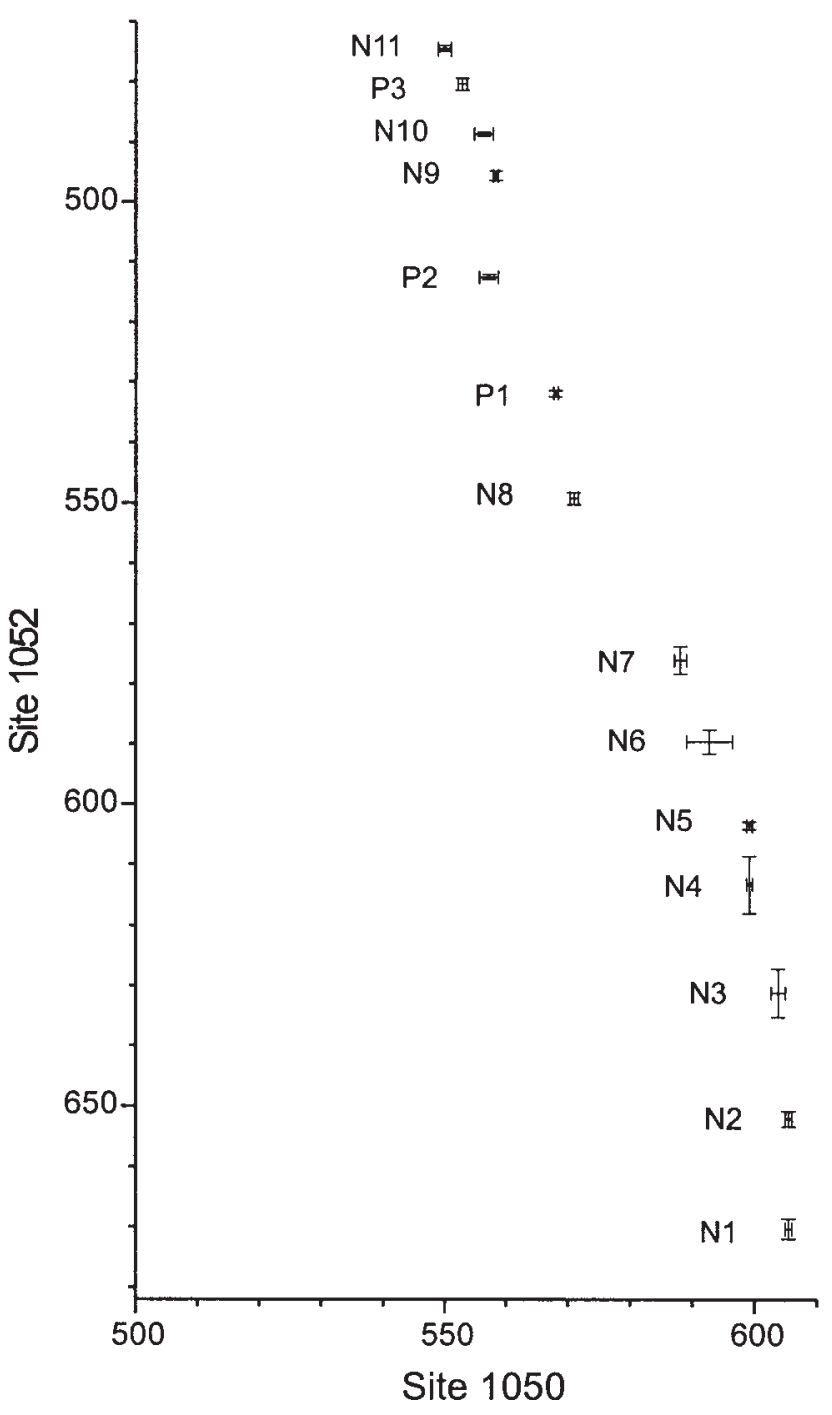

TEXT-FIGURE 6

Graphic correlation of Sites 1050 and 1052, based on the biostratigraphic distribution of the eiffellithids and planktonic foraminifers. Data for this graph are compiled in Table 3.

cies. In general, the different species first appeared as rare members of the eiffellithid population. This is clearly demonstrated by the distributions of E. equibiramus, E. vonsalisiae, E. turriseiffelii and, to a lesser degree, E. collis. This also appears to have been the case with E. praestigium, although the base of its stratigraphic range was not reached at Site 1052. The initial period of rare occurrence varied in duration from species to species, ranging from as much as $0.5 \mathrm{~m}$.y. in E. equibiramus to as little as 0.2 m.y. in E. turriseiffelii.

Following this period of initial rarity, the majority of the species underwent a rapid three- to five-fold increase in their relative abundance. This trend is clearly evident in E. praestigium, E. equibiramus, E. vonsalisiae, E. turriseiffelii, and, to a lesser extent, E. parvus (text-fig. 7). This significant increase in abundance occurred in a relatively short time, ranging from about 90 k.y. for E. praestigium to about 160 k.y. for E. equibiramus. A similar trend is evident from the distribution of the large $E$. 

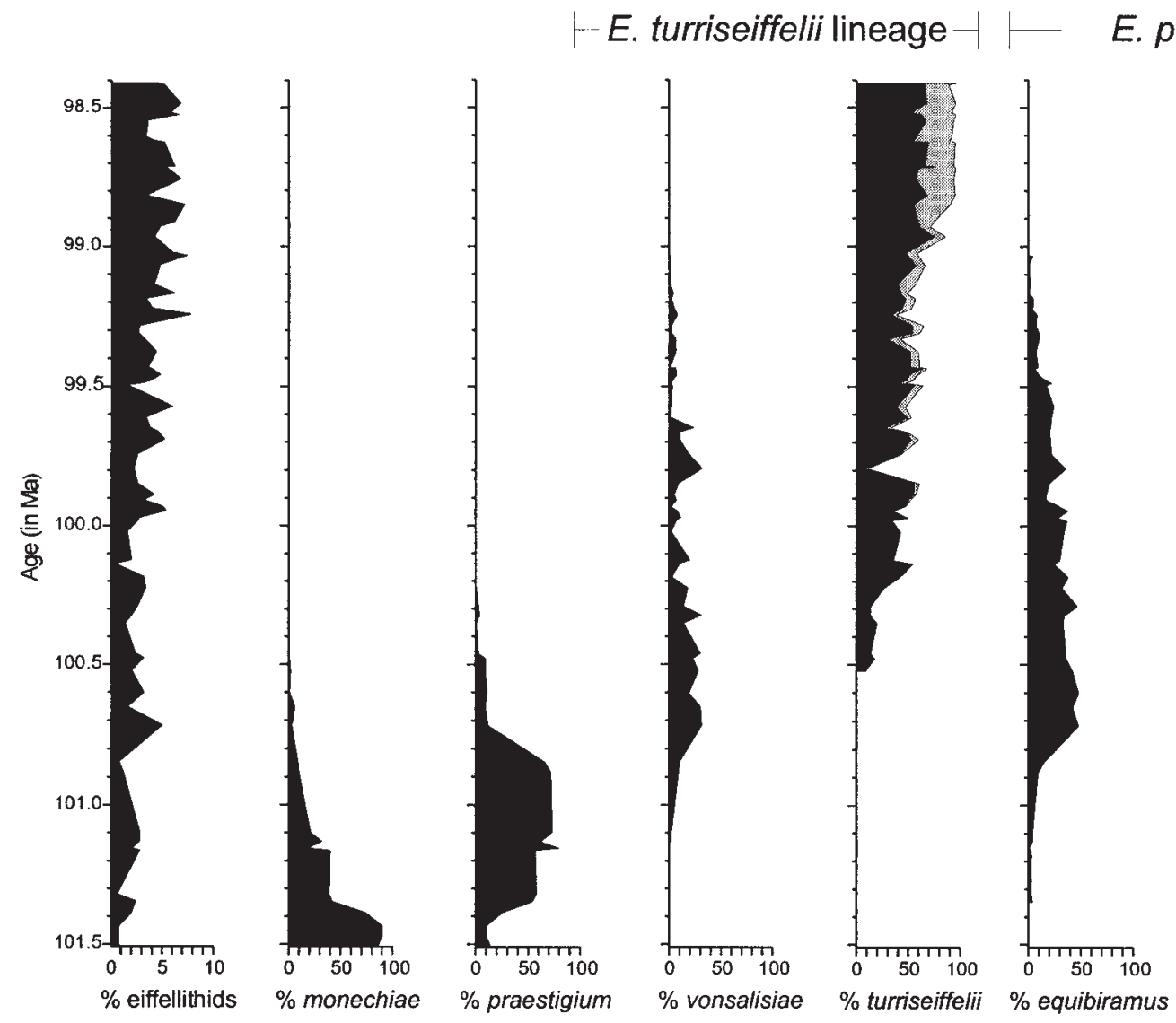

\section{E. parvus lineage}
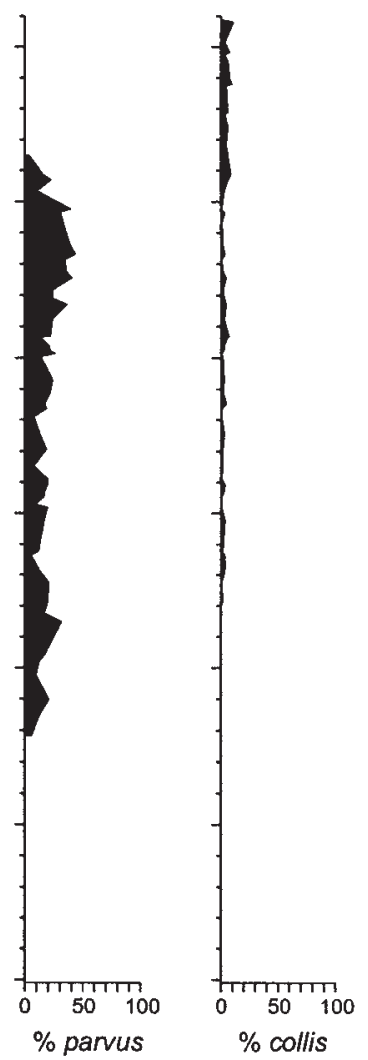

TEXT-FIGURE 7

Abundance distribution of the upper Albian and lower Cenomanian eiffellithids from the Leg 171B composite site. The lighter shading in the column for E. turriseiffelii indicates that abundance of the larger $(>8 \mu \mathrm{m})$ morphotype.

turriseiffelii morphotype, which underwent a three-fold increase in abundance in about $80 \mathrm{k} . \mathrm{y}$. near the Albian/Cenomanian boundary. The only morphotype that did not exhibit this phenomenon was $E$. collis, a species that never attained more than about $10 \%$ abundance of the eiffellithids in these sections.

The species tended to retain their relatively high abundances amongst the eiffellithid taxa throughout most of the rest of their duration, although there is considerable variation in abundance patterns. Both E. equibiramus and E. vonsalisiae exhibited their highest relative abundance immediately following their rapid rise to prominence. The small morphotype of E. turriseiffelii maintained its high abundance level for most of its range in the section. The abundances of E. praestigium and E. parvus actually increased slightly towards the end of their periods of dominance. The durations of these high abundance periods differed amongst species, varying from as little as $0.5 \mathrm{my}$. in $E$. praestigium to more than 1.6 my. in E.parvus. In the case of $E$. turriseiffelii, this phase of high abundance was sustained throughout the rest of the Cretaceous (more than 35 my.).

The interval of high abundance for all species tended to end abruptly, with a rapid decline in abundance down to levels of $<10 \%$. This is most graphically illustrated in the distribution of E. praestigium, which declined from abundances $>50 \%$ to sus- tained levels below $12 \%$ in approximately 130 k.y. Similar, albeit less dramatic, crashes in abundance were exhibited by $E$. equibiramus, E. vonsalisiae, E. parvus, and E. monechiae (text-fig. 7). The latter species exhibited the most gradual decline, taking more than $700 \mathrm{k} . \mathrm{y}$. to decrease to single-digit abundance levels. Following the precipitous decline, these species tended to end their duration much as they began them, with a period of relative obscurity at low levels of abundance. This is clearly illustrated by the abundance patterns of $E$. monechiae, $E$. praestigium, E. equibiramus, E. vonsalisiae, and, to a lesser extent, E. parvus.

The genus Eiffellithus grew in importance in calcareous nannoplankton communities through the late Albian, as indicated by their increase in relative abundance from $<1 \%$ of the total nannofossil assemblage at about 101.5 Ma to $>5 \%$ at about 98.5 Ma. The linear nature of this increase is clear from the high correlation coefficient of abundance versus age $(r=0.715$, $\mathrm{p}<0.0001)$ and from visual inspection of text-figures 7 and 8 . No significant, sustained increases in eiffellithids as a proportion of the total nannofossil assemblage accompanied the rapid increases in individual species (with the possible exception of the earliest episode, as described below). In a similar fashion, no significant, sustained decreases in eiffellithids as a proportion of the total nannofossil assemblage accompanied the rapid 


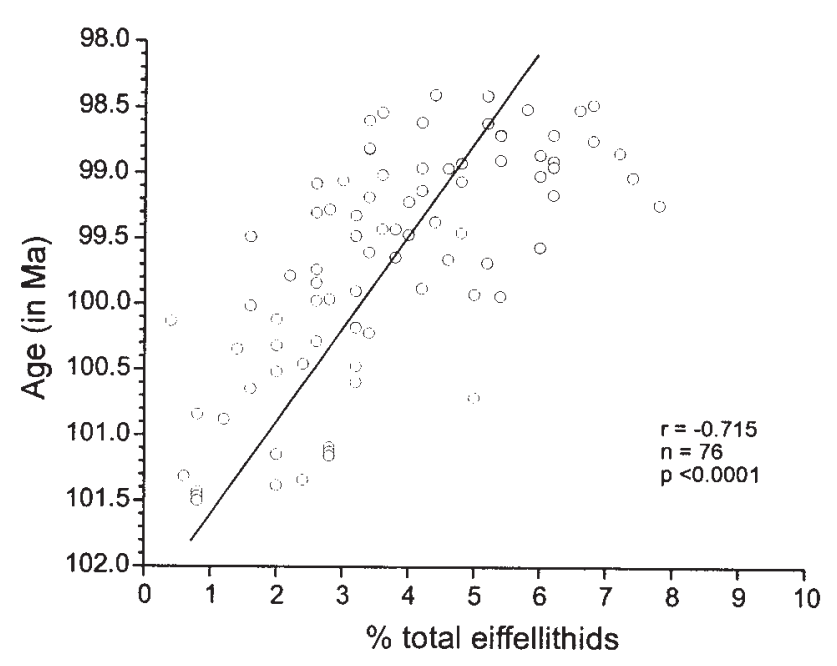

TEXT-FIGURE 8

Eiffellithid abundance through time. This illustrates the clear trend towards increasing importance of the genus during the late Albian and early Cenomanian. Once attained, the high relative abundance of eiffellithids is generally maintained throughout the rest of the Cretaceous.

decreases in individual species. These relationships indicate that species abundances must have increased at the expense of other eiffellithids, without substantively changing the overall carrying capacity of eiffellithids in the ecosystem. The relative abundance pattern for late Albian eiffellithids was the result of a series of abundance collapses by one set of species and a concomitant rise to dominance of new taxa.

The earliest of these turnover episodes occurred with the rapid dominance reversal of E. monechiae and E. praestigium at approximately 101.3 Ma (text-fig. 7). The high degree of variability in the total eiffellithid abundance for this interval renders it impossible to determine whether this episode represents the replacement of E. praestigium at the expense of E. monechiae or the addition of a larger standing population of E. praestigium to an extant population of E. monechiae. Given this limitation, it is possible that this episode may differ from the others.

The second episode, from about 100.7 to $100.8 \mathrm{Ma}$, was characterized by a significant re-organization of the genus Eiffellithus. It is at this time that the abundance of $E$. praestigium rapidly declined from a position of dominance (abundance $>60 \%$ ) to a minor role (abundance $<12 \%$ ). From this point onward, the early forms of Eiffellithus (i.e., E. monechiae and E. praestigium) further declined in abundance and ultimately suffered extinction. There was a concomitant rise in the fortunes of the E. parvus lineage (text-fig. 9), as $E$. equibiramus rapidly increased in abundance (from $<10 \%$ to $>32 \%$ ) and the species E. parvus evolved.

A third episode of dominance shift occurred between 99.4 and 99.5 Ma. During this episode, E. equibiramus declined sharply from average abundance $>25 \%$ to average values of $<6 \%$. There was a simultaneous rise in the abundance of E. parvus, from average abundance of about $16 \%$ to average values of $>34 \%$. Following this dominance shift, only E. parvus and $E$. turriseiffelii had relative abundance $>10 \%$ of all eiffellithids.

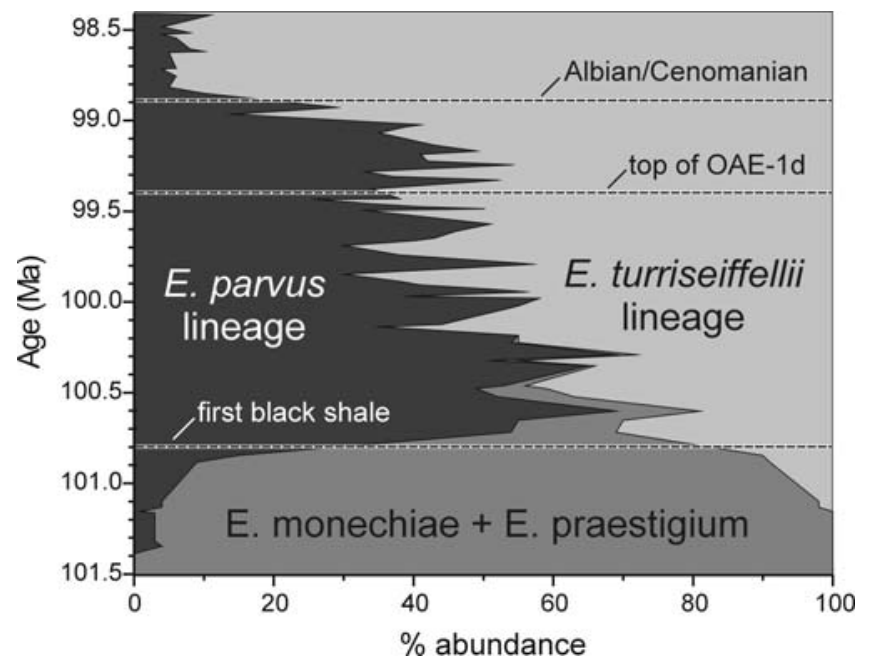

TEXT-FIGURE 9

Distribution of the three major groups of upper Albian eiffellithids and their relationship to the onset of black shale deposition and the Albian/Cenomanian boundary.

The final episode occurred near the Albian-Cenomanian boundary, when there was a significant consolidation within the genus. Eiffellithus equibiramus and E. vonsalisiae suffered extinction just prior to the boundary, while E. parvus fell to extinction just after the boundary. Although there was a slight increase in the abundance of $E$. collis in the early Cenomanian, it was E. turriseiffelii that rapidly rose to commanding dominance, with abundance levels in excess of $90 \%$. More specifically, it was the large morphotype (i.e., the typical morphotype) that rapidly increased accompanying the extinction of its sister species. It was this larger morphotype that eventually became the dominant eiffellithid for the remainder of the Cretaceous.

\section{Environmental forcing of Evolutionary Changes}

It is axiomatic that environmental change drives the evolution of species, although it is not often easy to identify the exact environmental factors that are responsible for the changes in the biota. In the case of the mid-Cretaceous eiffellithids, three of the four dominance shifts corresponded with significant changes in the paleoenvironment, as indicated by the lithologic record. The earliest dominance shift, in which E. praestigium rapidly increased to dominance, is not associated with any obvious change in sedimentological character.

The second dominance shift, corresponding to the rapid decrease of E. praestigium and the rise of E. equibiramus, is coincident with the earliest laminated black shale in the upper Albian section of the Blake Nose (text-fig. 9) and the base of lithologic Subunit Vb. Wilson and Norris (2001) document a negative $\delta^{13} \mathrm{C}$ excursion of approximately $-1 \%$ in both surface and thermocline-dwelling planktonic foraminifers corresponding to this first black shale episode. Following the recovery from this short negative excursion, carbon isotope values of both surface and thermocline species exhibited a steady and gradual decline through Unit $\mathrm{Vb}$. Oxygen isotope values for thermocline-dwelling species became progressively more negative through Unit $\mathrm{Vb}$, suggesting a gradual warming of the thermocline. This trend culminated with the collapse of the vertical stratification of the upper water column and with the peak 


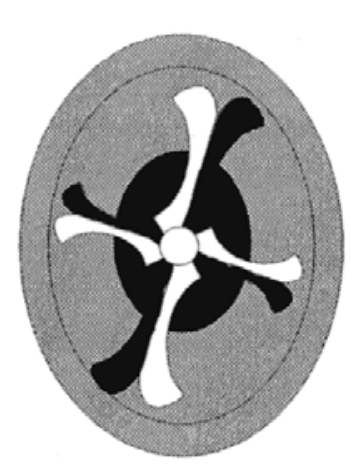

a

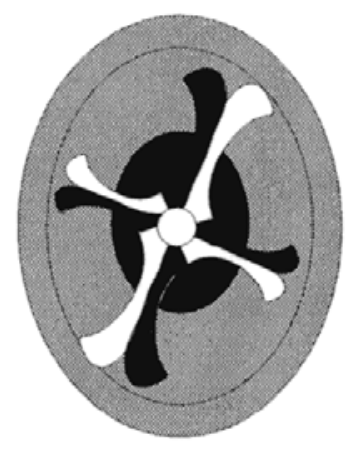

b
TEXT-FIGURE 10

Schematic diagram illustrating the shift of birefringence that results in the "trick" in the cross polarized images of E. praestigium.

intensity in laminated black shale deposition, corresponding to OAE-1d (Wilson and Norris 2001).

The third dominance shift, in which E. equibiramus declined while E. parvus increased in abundance, occurred just above the deposition of the last (upper Albian) black shale (top of lithologic Subunit Vb) in Hole 1052E. This horizon marks the end of OAE- $1 \mathrm{~d}$, and is associated with a positive $\delta$ C excursion of $>2 \% o$ at Site 1052 (Wilson and Norris 2001). This horizon marked the end of the peak in the conditions thaşresulted in significant organic carbon deposition, although the sediment continued to accumulate under dysoxic conditions until the end of the Albian, as is illustrated in the elevated total organic carbon (TOC) levels in the uppermost Albian of Hole 1050C (Norris et al. 1998).

The final dominance shift, characterized by the extinctions of E. equibiramus and E. parvus and the rise to almost total dominance of E. turriseiffelii, occurred near the Albian/Cenomanian boundary. This interval in Hole $1050 \mathrm{C}$ coincides with a lithologic change from dark nannofossil claystones below (lithologic Subunit VIb; Albian) to light nannofossil chalk and limestone above (lithologic Subunit VIa; Cenomanian). This change is reflected in the fact that the average TOC value for samples within $25 \mathrm{~m}$ below the boundary is $0.65 \mathrm{wt} . \%$, while the average for samples within $25 \mathrm{~m}$ above the boundary are only 0.18 wt.\% (Norris et al. 1998).

There is a clear relationship between the E. parvus lineage and the conditions in the water column that led to the deposition of organic-rich sediments (text-fig. 9). The onset of deposition of black shale and associated organic-rich facies coincided with the crash of the early eiffellithids (E. monechiae and E. praestigium), the rapid ascendancy of E. equibiramus, and the evolution of $E$. parvus. These two species constituted an average of $>45 \%$ of the eiffellithids during the period of organic-rich sediment deposition. The first part of this interval was dominated by E. equibiramus, including the entire duration of OAE-1d. The end of OAE-1d brought a rapid decline in $E$. equibiramus, but its replacement by E. parvus coincided wth no significant decrease in the abundance of the E. parvus lineage as a whole (text-fig. 9). The end of deposition of organic-rich facies at the Albian/Cenomanian boundary brought the decline of E. parvus and the ultimate extinction of both E. parvus and $E$. equibiramus.

Throughout this interval of organic-rich sediment deposition, the E. turriseiffelii lineage constituted an average of approximately $54 \%$ of the eiffellithids. This portion was dominated initially by $E$. vonsalisiae, although this species declined and ultimately went extinct as E. turriseiffelii gained complete dominance. The concomitant rise in overall eiffellithid abundance during this interval suggests that E. turriseiffelii was also displacing some non-eiffellithid(s) in the nannoplankton community. The reduction of the E. parvus lineage to the rare E. collis near the Albian/Cenomanian boundary coincided with the increase in abundance of the large morphotype of E. turriseiffelii. This suggests that the termination of the niche space formerly occupied by E. parvus and E. equibiramus led to establishment of a new type of niche space that favored the large E. turriseiffelii morphotype. The persistence and general stability of this morphotype to the end of the Cretaceous suggests it filled a niche space that remained relatively unaltered for almost 35 m.y.

\section{CONCLUSIONS}

The characteristics that typify the genus Eiffellithus were established in the ancestral species (E. monechiae) during the early late Albian. Once established, these characteristics persisted in a basically unchanged form for the rest of the (Cretaceous) history of the genus. Analysis of the biostratigraphic (text-fig. 3) and abundance distribution (text-fig. 7) indicates that the radiation of the eiffellithids in the late Albian and early Cenomanian occurred as a series of species evolved, rose to dominance, then rapidly declined to extinction, to be replaced by other members of the genus. The stratigraphic record from Leg 171B suggests that this was not a gradual process, but rather was punctuated by a series of pulses of major reorganization within the genus. Newly evolved species tended to remain at low abundance levels until a significant disruption in the pelagic realm resulted in the precipitous decline of the dominant species, providing open niche space into which the new species could rapidly rise to dominance. All of the species discussed herein exhibited this pattern to a greater or lesser degree, except E. collis, a species whose niche apparently never arrived.

The rise to dominance of the E. parvus lineage and concomitant decline of the early eiffellithids (E. monechiae and $E$. praestigium) corresponded with the initiation of black shale deposition. The end of black shale deposition (= the top of OAE-1d) corresponded with the abundance reversal of $E$. equibiramus and E. parvus. The end of deposition of organic-rich facies was associated with the rapid decline and extinction of E. equibiramus and E. parvus, and with the rapid rise in abundance of E. turriseiffelii (especially the larger morphotype). The fact that these species reacted differently to major shifts in surface water character suggests that they speciated and radiated into distinctly different niches or adaptive zones, thus fitting the classic definition of an adaptive radiation. This process of adaptive radiation resulted in the establishment of E. turriseiffelii as an abundant and morphologically stable component of Late Cretaceous nannoplankton communities.

\section{ACKNOWLEDGMENTS}

This research used samples and data provided by the Ocean Drilling Program. The ODP is sponsored by the U.S. National 
TABLE 1

Nannofossil abundance distribution in the Albian and Cenomanian of ODP Hole 1050C. The age listed is that derived from the age model for this succession. The column "\% eiffellithids" expressed the abundance of all eiffellithid species as a percentage of the total nannofossil assemblage. The columns for different species give the abundance of each species as a percentage of the total eiffellithids in the sample. Species counts have been rounded to the nearest integer on the chart for convenience.

\begin{tabular}{|c|c|c|c|c|c|c|c|c|c|}
\hline $\begin{array}{l}\frac{\text { 을 }}{\text { E⿸厂巳 }} \\
\text { है }\end{array}$ & 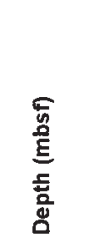 & 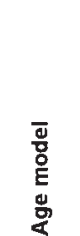 & 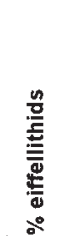 & $\begin{array}{l}\text { 翌 } \\
\text { 号 } \\
\text { 山i }\end{array}$ & 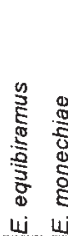 & 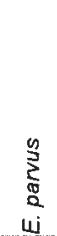 & 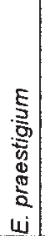 & 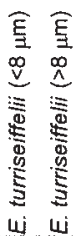 & 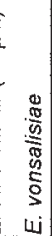 \\
\hline $21 R-1,0-1$ & 500.21 & & $5.0 \%$ & 5 & & & & $66 \quad 29$ & \\
\hline $21 R-2,54-55$ & 502.24 & & $7.2 \%$ & 3 & & & & $58 \quad 39$ & \\
\hline $21 R-4,38-39$ & 505.08 & & $7.8 \%$ & 5 & & & & 4253 & \\
\hline $21 R-5,01$ & 506.21 & & $5.6 \%$ & 11 & & & & $53 \quad 36$ & \\
\hline $21 R-6,24-25$ & 507.95 & & $3.8 \%$ & 5 & & & & $51 \quad 44$ & \\
\hline $22 R-1,8-9$ & 509.88 & 98.41 & $4.4 \%$ & 3 & & & & $\begin{array}{ll}60 & 37\end{array}$ & \\
\hline $22 \mathrm{R}-\mathrm{CC}$ & 510.40 & 98.42 & $5.2 \%$ & 11 & & & & $66 \quad 23$ & \\
\hline $23 R-1,16-17$ & 519.56 & 98.48 & $6.8 \%$ & 4 & & & & 6828 & \\
\hline $23 R-3,124-125$ & 523.65 & 98.52 & $5.8 \%$ & 8 & & & & $53 \quad 39$ & \\
\hline $23 R-4,77-78$ & 524.67 & 98.53 & $6.6 \%$ & 4 & & & & 6333 & \\
\hline $23 R-6,41-43$ & 527.30 & 98.55 & $3.6 \%$ & 6 & & & & $\begin{array}{ll}67 & 27\end{array}$ & \\
\hline $24 R-1,96-97$ & 530.06 & 98.61 & $3.4 \%$ & 8 & & & & $58 \quad 34$ & \\
\hline $24 R-2,70-71$ & 531.30 & 98.62 & $4.2 \%$ & 10 & & & & 5436 & \\
\hline $24 \mathrm{R}-3,41-42$ & 531.90 & 98.63 & $5.2 \%$ & 5 & & & & 6926 & \\
\hline $25 R-1,144-145$ & 540.14 & 98.71 & $6.2 \%$ & 6 & & & & $66 \quad 28$ & \\
\hline $25 R-3,147-148$ & 540.17 & 98.71 & $5.4 \%$ & 5 & & & & $77 \quad 18$ & \\
\hline $25 R-2,40-41$ & 540.60 & 98.72 & $5.4 \%$ & 4 & & & & 6036 & \\
\hline $25 R-C C$ & 544.05 & 98.76 & $6.8 \%$ & 6 & & & & $58 \quad 36$ & \\
\hline $26 R-1,55-56$ & 548.95 & 98.82 & $3.4 \%$ & 5 & & & & $\begin{array}{ll}68 & 27\end{array}$ & \\
\hline $26 R-2,112-113$ & 551.02 & 98.85 & $7.2 \%$ & 6 & & 4 & & $55 \quad 35$ & \\
\hline $26 R-5,38-39$ & 554.79 & 98.91 & $6.2 \%$ & 9 & & 16 & & 6045 & \\
\hline $26 \mathrm{R}-\mathrm{CC}$ & 557.90 & 98.96 & $6.2 \%$ & 16 & 2 & 32 & & 473 & $P$ \\
\hline $27 R-1,72-73$ & 558.72 & 98.97 & $4.6 \%$ & 5 & 4 & 26 & & 538 & 4 \\
\hline $27 \mathrm{R}-3,131-132$ & 562.31 & 99.02 & $3.6 \%$ & 5 & 14 & 13 & & $56 \quad 10$ & 2 \\
\hline $27 \mathrm{R}-6,15-16$ & 565.65 & 99.06 & $3.0 \%$ & 9 & 22 & 22 & & $42 \quad 3$ & 2 \\
\hline 27R-CC & 567.50 & 99.09 & $2.6 \%$ & 7 & 23 & 28 & & $39 \quad 2$ & 1 \\
\hline $28 \mathrm{R}-1,78-79$ & 568.38 & & $4.0 \%$ & 7 & 25 & 23 & & $37 \quad 4$ & 4 \\
\hline $28 \mathrm{R}-2,115-116$ & 570.25 & & $2.0 \%$ & 9 & 28 & 18 & & 394 & 2 \\
\hline $28 R-3,100-101$ & 571.60 & & $4.0 \%$ & 2 & 30 & 24 & & 38 & 6 \\
\hline $28 \mathrm{R}-4,102-103$ & 573.12 & & $3.2 \%$ & 7 & 30 & 22 & & 38 & 3 \\
\hline $28 \mathrm{R}-5,28-29$ & 573.88 & & $2.4 \%$ & \begin{tabular}{|l|}
6 \\
\end{tabular} & 27 & $\frac{2}{12}$ & & 52 & 3 \\
\hline $28 \mathrm{R}-6,106-107$ & 576.16 & & $4.2 \%$ & 10 & 27 & 26 & & 29 & 8 \\
\hline $28 R-C C$ & 577.10 & & $0.8 \%$ & 15 & 30 & 12 & & 28 & 15 \\
\hline $29 \mathrm{R}-1,115-116$ & 578.35 & & $1.4 \%$ & 14 & 33 & 33 & & 6 & 14 \\
\hline $29 \mathrm{R}-2,88-89$ & 579.58 & & $2.6 \%$ & 6 & 36 & 23 & & 20 & 15 \\
\hline $29 R-3,7-8$ & 580.27 & & $2.0 \%$ & 8 & 28 & 34 & & 19 & 11 \\
\hline $29 R-4,82-83$ & 582.52 & & $2.6 \%$ & 4 & 37 & 23 & & 13 & 23 \\
\hline $29 \mathrm{R}-5,48-49$ & 583.69 & & $2.4 \%$ & 7 & 33 & 26 & & 19 & 15 \\
\hline $29 R-6,61-62$ & 585.31 & & $2.6 \%$ & 6 & 37 & 28 & & 13 & 16 \\
\hline $29 \mathrm{R}-\mathrm{CC}$ & 586.70 & & $3.2 \%$ & 6 & 28 & 29 & $\mathbf{R}$ & 10 & 27 \\
\hline $30 R-1,35-36$ & 587.15 & & $2.6 \%$ & 4 & 28 & 30 & $\mathrm{R}$ & 6 & 32 \\
\hline $30 R-2,77-78$ & 589.07 & & $2.8 \%$ & 7 & 40 & 13 & 20 & $\mathrm{R}$ & 20 \\
\hline 30R-CC & 596.40 & & $3.2 \%$ & & 32 & 1 & 50 & $\mathrm{R}$ & 17 \\
\hline$-1,47-48$ & 596.87 & & $1.8 \%$ & & 30 & 6 & 57 & $\mathrm{R}$ & 7 \\
\hline $31 \mathrm{R}-2,76-77$ & 598.66 & & $2.2 \%$ & & 40 & 12 & 48 & $R$ & $\mathrm{R}$ \\
\hline $31 R-3,19-20$ & 599.59 & & $2.8 \%$ & & 201 & 22 & 57 & & $R$ \\
\hline$-4,121-123$ & 602.11 & & $3.2 \%$ & & 24 & 12 & 59 & & $R$ \\
\hline $5,22-23$ & 602.62 & & $3.6 \%$ & & 354 & 1 & 60 & & $\mathrm{R}$ \\
\hline 31R-6, 99-100 & 604.90 & & $2.4 \%$ & & 101 & & 76 & & $\mathrm{R}$ \\
\hline $31 \mathrm{R}-\mathrm{CC}$ & 605.95 & & $2.4 \%$ & & 37 & & 63 & & \\
\hline
\end{tabular}

Science Foundation (NSF) and participating countries under management of Joint Oceanographic Institutions (JOI), Inc. Funding for this research was provided by JOI-USSAC and National Science Foundation Grant INT-9910025 to DKW. This manuscript was improved by comments from Debra Beck and Jean Self-Trail. Formal reviews by R. Mark Leckie and Timothy J. Bralower were thorough and detailed. Their advice significantly improved the final product.
TABLE 2

Nannofossil abundance distribution in the Albian and Cenomanian of ODP Hole 1052E. The age listed is that derived from the age model for this succession. The column "\% eiffellithids" expressed the abundance of all eiffellithid species as a percentage of the total nannofossil assemblage. The columns for different species give the abundance of each species as a percentage of the total eiffellithids in the sample. Species counts have been rounded to the nearest integer on the chart for convenience.

\begin{tabular}{|c|c|c|c|c|c|c|c|c|c|}
\hline 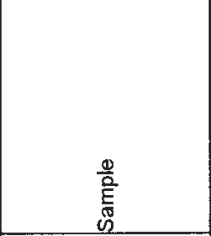 & 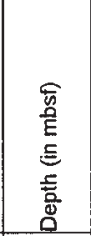 & $\begin{array}{l}\bar{\Phi} \\
\overline{0} \\
\mathrm{E} \\
\bar{D} \\
\stackrel{9}{8} \\
\end{array}$ & 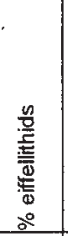 & 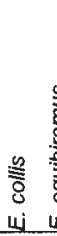 & 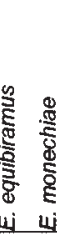 & & 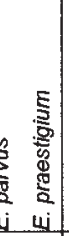 & 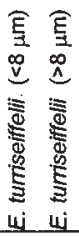 & 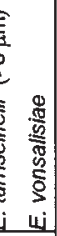 \\
\hline $36 \mathrm{R}-1,118-119 \mathrm{~cm}$ & 474.34 & 98.82 & $3.4 \%$ & 6 & & & 3 & 6823 & \\
\hline $36 \mathrm{R}-3,143-144 \mathrm{~cm}$ & 477.63 & 98.87 & $6.0 \%$ & 2 & & & 31 & $56 \quad 11$ & 1 \\
\hline $36 \mathrm{R}-5,110-111 \mathrm{~cm}$ & 480.31 & 98.90 & $5.4 \%$ & 3 & & & 23 & $60 \quad 14$ & 4 \\
\hline $36 R-6,132-135$ & 482.02 & 98.93 & $4.8 \%$ & 6 & & & 23 & $61 \quad 10$ & 0 \\
\hline $37 R-2,31-32$ & 484.61 & 98.97 & $4.2 \%$ & 3 & & & 11. & $75 \quad 11$ & 1 \\
\hline $37 \mathrm{R}-4,111-114 \mathrm{~cm}$ & 488.41 & 99.02 & $6.0 \%$ & 1 & & & 40 & $48 \quad 11$ & 1 \\
\hline $37 \mathrm{R}-5,28-31 \mathrm{~cm}$ & 489.08 & 99.03 & $7.4 \%$ & 4 & 4 & & 31 & $50 \quad 10$ & 0 \\
\hline $37 R-6,73-74$ & 491.03 & 99.07 & $4.8 \%$ & 1 & & & 33 & & 9 \\
\hline $38 \mathrm{R}-2,92-95 \mathrm{~cm}$ & 494.82 & 99.14 & $4.2 \%$ & 2 & 2 & & 39 & & \\
\hline $38 R-3,103-106$ & 496.43 & 99.17 & $6.2 \%$ & 4 & & & 13 & 436 & 6 \\
\hline $38 \mathrm{R}-4,47-50 \mathrm{~cm}$ & 497.37 & 99.19 & $3.4 \%$ & 1 & 5 & & 35 & & 9 \\
\hline $38 R-5,101-104$ & 499.41 & 99.22 & $4.0 \%$ & 2 & 4 & & 36 & $44 \quad 9$ & 9 \\
\hline $38 \mathrm{R}-6,54-57 \mathrm{~cm}$ & 500.64 & 99.24 & $7.8 \%$ & 5 & 8 & & 41 & & 4 \\
\hline $39 R-1,95-98$ & 502.95 & 99.28 & $2.8 \%$ & 2 & 7 & & 24 & $54 \quad 11$ & 1 \\
\hline $39 R-2,82-85$ & 504.32 & 99.31 & $2.6 \%$ & & 10 & & 24 & & 7 \\
\hline $39 R-3,16-19$ & 505.16 & 99.33 & $3.2 \%$ & 5 & 10 & & 37 & $30 \quad 12$ & 2 \\
\hline $39 R-4,54-57$ & 507.04 & 99.38 & $4.4 \%$ & 3 & 7 & & 24 & & 8 \\
\hline $39 R-7,24-25$ & 510.76 & 99.43 & $3.6 \%$ & 7 & 9 & & 22 & 529 & 9 \\
\hline $40 R-1,41-44$ & 511.01 & 99.43 & $3.8 \%$ & 6 & 6 & & 14 & & 5 \\
\hline 4OR-2, $118-121$ & 513.28 & 99.46 & $4.8 \%$ & 3 & 10 & & 21 & $50 \quad 9$ & 9 \\
\hline $40 R-3,126-129$ & 514.86 & 99.48 & $4.0 \%$ & 3 & 16 & & 22 & & 6 \\
\hline $40 R-4,67-70$ & 515.77 & 99.49 & $3.2 \%$ & 1 & 22 & & 27 & 417 & 7 \\
\hline $40 R-5,47-50$ & 516.57 & 99.50 & $1.6 \%$ & 2 & 17 & & 14 & 568 & 8 \\
\hline $41 \mathrm{R}-1,98-101 \mathrm{~cm}$ & 521.28 & 99.57 & $6.0 \%$ & 3 & 24 & & 24 & 398 & 8 \\
\hline $41 R-3,52-54$ & 523.82 & 99.61 & $3.4 \%$ & 2 & 22 & & 22 & $49 \quad 4$ & 4 \\
\hline $41 R-5,50-52$ & 526.80 & 99.65 & $3.8 \%$ & 5 & 21 & & 17 & 285 & 524 \\
\hline $41 R-6,20-22$ & 528.00 & 99.66 & $4.6 \%$ & 1 & 20 & & 19 & & 110 \\
\hline $42 R-1,30-33$ & 530.20 & 99.69 & $5.2 \%$ & 1 & 21 & & 8 & 537 & $\begin{array}{ll}7 & 10\end{array}$ \\
\hline $42 \mathrm{R}-3,63-65 \mathrm{~cm}$ & 533.53 & 99.74 & $2.6 \%$ & 3 & 22 & & 13 & 412 & 219 \\
\hline $42 \mathrm{R}-5,63-65 \mathrm{~cm}$ & 536.53 & 99.79 & $2.2 \%$ & 2 & 36 & & 19 & 83 & 332 \\
\hline $43 \mathrm{R}-1,80-83 \mathrm{~cm}$ & 540.30 & 99.85 & $2.6 \%$ & 2 & 20 & & 8 & & 5 \\
\hline $43 \mathrm{R}-3,60-63 \mathrm{~cm}$ & 543.10 & 99.89 & $4.2 \%$ & 1 & 17 & & 20 & 552 & 2 \\
\hline $43 R-4,97-100$ & 544.97 & 99.91 & $3.2 \%$ & 4 & 17 & & 20 & $50 \quad 2$ & 2 \\
\hline $43 R-6,127-130$ & 548.27 & 99.93 & $5.0 \%$ & 3 & 31 & & 17 & $46 \quad 1$ & \\
\hline $44 \mathrm{R}-1,118-121$ & 550.28 & 99.94 & $5.4 \%$ & 1 & 38 & & 17 & 36 & 8 \\
\hline $44 R-4,7-10$ & \begin{tabular}{|l|}
553.67 \\
\end{tabular} & 99.97 & $2.8 \%$ & 1 & 28 & & 10 & 50 & 11 \\
\hline $44 R-5,18-21$ & 555.28 & 99.98 & $2.6 \%$ & $i$ & 37 & & 20 & 35 & 7 \\
\hline $45 \mathrm{R}-1,122-125 \mathrm{~cm}$ & 559.92 & 100.02 & $1.6 \%$ & 4 & 34 & & 17 & 43 & 2 \\
\hline $46 R-1,62-65$ & 568.92 & 100.12 & $2.0 \%$ & 2 & 30 & & 12 & 36 & 20 \\
\hline $46 R-2,67-70$ & 569.92 & 100.14 & $0.4 \%$ & 4 & 25 & & 6 & 55 & 10 \\
\hline $46 \mathrm{R}-5,7-10 \mathrm{cr}$ & 573.73 & 100.18 & $3.2 \%$ & 4 & 38 & & 13 & 42 & \\
\hline $47 \mathrm{R}-1,36-39 \mathrm{~cm}$ & 578.36 & 100.22 & $3.4 \%$ & 1 & 32 & & 21 & 27 & 18 \\
\hline $48 R-1,3-6$ & 587.63 & 100.29 & $2.6 \%$ & 2 & 47 & & 20 & 14 & 14 \\
\hline $48 \mathrm{R}-3,43-46 \mathrm{~cm}$ & 591.06 & 100.32 & $2.0 \%$ & & 34 & & 17 & 14 & 31 \\
\hline $48 R-6,147-150$ & 593.57 & 100.35 & $1.4 \%$ & & 33 & & 32 & 20 & 14 \\
\hline $49 R-4,111-114$ & 602.91 & 100.46 & $2.4 \%$ & & 36 & & $\frac{17}{17}$ & 14 & 30 \\
\hline $49 R-5,89-92$ & 604.19 & 100.48 & $3.2 \%$ & & 36 & 11 & 13 & 18 & 23 \\
\hline $50 \mathrm{R}-2,23-26 \mathrm{~cm}$ & 608.63 & 100.52 & $2.0 \%$ & & 42 & 2 & $\begin{array}{ll}10 & 9\end{array}$ & 9 & 28 \\
\hline $51 \mathrm{R}-2,3-6 \mathrm{~cm}$ & 618.13 & 100.60 & $3.2 \%$ & & 48 & - & $21 \quad 11$ & & 19 \\
\hline $52 \mathrm{R}-1,40-43 \mathrm{~cm}$ & 622.10 & 100.65 & $1.6 \%$ & & 42 & & 139 & & 30 \\
\hline $52 R-4,100-103$ & 627.20 & 100.72 & $5.0 \%$ & & 48 & 3 & $\begin{array}{ll}6 & 12 \\
\end{array}$ & & 31 \\
\hline $53 R-C C$ & 635.30 & 100.85 & $0.8 \%$ & & 15 & 9 & 66 & & 10 \\
\hline $54 \mathrm{R}-1,37-40 \mathrm{~cm}$ & 637.17 & 100.88 & $1.2 \%$ & & 91 & 10 & 72 & & 9 \\
\hline $55 \mathrm{R}-2,0-3 \mathrm{~cm}$ & 647.90 & 101.10 & $2.8 \%$ & & 42 & 21 & 73 & & 2 \\
\hline $55 \mathrm{R}-3,147-150 \mathrm{~cm}$ & 650.87 & 101.13 & $2.8 \%$ & & 43 & 32 & & & \\
\hline $55 R-5,94-97$ & 653.34 & 101.15 & $2.0 \%$ & & 11 & 19 & 80 & & \\
\hline $55 \mathrm{R}-6,16-19 \mathrm{~cm}$ & 654.06 & 101.16 & $2.8 \%$ & & 34 & 40 & & & \\
\hline 57R-1, 96-99 & 666.56 & 101.32 & $0.6 \%$ & & 33 & 39 & 58 & & \\
\hline $57 R-3,54-57$ & 668.64 & 101.35 & $2.4 \%$ & & 44 & 42 & & & \\
\hline $57 R-5,83-86$ & 671.93 & 101.39 & $2.0 \%$ & & & 74 & 26 & & \\
\hline $58 \mathrm{R}-1,64-67 \mathrm{~cm}$ & 675.84 & 101.44 & $0.8 \%$ & & & 90 & 10 & & \\
\hline $58 R-3,40-43$ & 678.60 & 101.47 & $0.8 \%$ & & & 90 & & & \\
\hline $58 \mathrm{R}-5,24-28 \mathrm{~cm}$ & 681.44 & 101.51 & $0.8 \%$ & & & 86 & 14 & & \\
\hline
\end{tabular}


TABLE 3

Data used for graphic correlation of Sites 1050 and 1052. Codes are used to identify data points in Fig. 6. Planktonic foraminifer data are from Bellier et al. (2001).

\begin{tabular}{lccccc} 
& \multicolumn{2}{c}{ 1052E } & \multicolumn{2}{c}{ 1050C } & \\
Datum & Max. depth & Min. depth & Max. depth & Min. depth & Code \\
Calcareous nannofossils & & & & & \\
LAD E. parvus & 475 & 474 & 551.02 & 548.95 & N11 \\
LAD E. equibiramus & 489.08 & 488.41 & 557.90 & 554.79 & N10 \\
LAD E. vonsalisiae & 496.43 & 494.82 & 558.72 & 557.90 & N9 \\
FAD E. turris. $(>8 \mu \mathrm{m})$ & 550.28 & 548.27 & 571.60 & 570.25 & N8 \\
LAD E. praestigium & 578.36 & 573.73 & 589.07 & 587.15 & N7 \\
FAD E. collis & 591.63 & 587.63 & 596.4 & 589.07 & N6 \\
LAD E. monechiae & 604.19 & 602.91 & 599.59 & 598.66 & N5 \\
FAD E. turriseiffelii & 618.03 & 608.63 & 599.59 & 598.66 & N4 \\
FAD E. parvus & 635.30 & 627.20 & 604.90 & 602.62 & N3 \\
FAD E. vonsalisiae & 653.34 & 650.87 & 605.95 & 604.90 & N2 \\
FAD E. equibiramus & 671.93 & 668.64 & 605.95 & 604.90 & N1 \\
& & & & & \\
Planktonic foraminifers & & & & & \\
FAD R. globotruncanoides & 481.38 & 479.42 & 553.59 & 552.08 & P3 \\
FAD . ticinensis & 513.02 & 512.10 & 558.69 & 555.60 & P2 \\
FAD G. appenninica & 532.44 & 531.40 & 568.35 & 567.65 & P1 \\
& & & & &
\end{tabular}

\section{SYSTEMATIC PALEONTOLOGY}

Class PRYMNESIOPHYCEAE (Hibberd 1976) Subclass PRYMNESIOPHYCIDAE (Cavalier-Smith 1994) Order EIFFELLITHALES (Rood, et al. 1971)

Family EIFFELLITHACEAE (Reinhardt 1965)

Genus Eiffellithus (Reinhardt 1965)

Eiffellithus equibiramus Watkins and Bergen, n. sp. Plate 2, figures 1-6; Plate 4, figure 4

Etymology: (L.) equi + bi + ramus; "two equal branches", referring to distinctive construction of the arms of the cross that forms the stem base.

Diagnosis: Medium, normally elliptical, eiffellithid with stem base consisting of four arms forming symmetrical a diagonal cross, with each arm composed of two, subequal, rectangular, disjunct crystal-units with blunt distal tips divided by a prominent central suture.

Description: This species has a normally to narrowly elliptical rim which is smooth to slightly serrate in outline. The outer rim is thin $(<1 \mu \mathrm{m})$ and composed of 35 to 50 steeply inclined elements. The inner rim is composed of blocky elements that are $1-1.5 \mu \mathrm{m}$ wide. The rims exhibit a first order white birefringence. A small ( 3 to $4 \mu \mathrm{m}$ ) round hole characterizes the middle of the central area. A symmetrical, diagonal cross that supports a small hollow stem spans the central hole. The four arms of the cross are composed to two sub-parallel sets of elements, each of which is lath-shaped, yielding an arm outline that is distinctly rectangular (approximately $2 \times 1 \mu \mathrm{m}$ ) in shape.
Measurements:

Length $=5.2-6.8 \mu \mathrm{m}(\mu=6.0$, s.d. $=0.4, \mathrm{n}=30)$

Width $=3.6-5.6 \mu \mathrm{m}(\mu=4.4$, s.d. $=0.5, \mathrm{n}=30)$

Eccentricity $=1.2-1.5(\mu=1.36$, s.d. $=0.1, \mathrm{n}=30)$

Remarks: The prominent, rectangular arms of this relatively small form are the most distinctive features of this species. The earliest forms of this taxon include specimens with a symmetrical cross that is offset from the diagonal position by as much as $10^{\circ}$. These forms appear to be transitional with E. praestigium, hence the proposed link between $E$. praestigium and $E$. equibiramus in text-figure 3 . There are, however, relatively few specimens from Leg 171B that are morphologically transitional between these two taxa.

Eiffellithus turriseiffelii resembles a small morphotype of $E$. equibiramus in the symmetrical diagonal stem base. They can be differentiated by the morphology of the cross arms, which are rectangular and prominently bisected by a suture in $E$. equibiramus as opposed to distally tapering to a point in $E$. turriseiffelii. Eiffellithus parvus and E. equibiramus are of similar size range (5-7 $\mu \mathrm{m}$ length; text-fig. 4), have symmetrical diagonal crosses, and have similar stratigraphic ranges (text-fig. 3 ). They are differentiated by the overall outline of the cross, which in plan view is a symmetrical diagonal cross in $E$. equibiramus but a compact rectangle in E. parvus. In addition, the crossbars in E. equibiramus are clearly divided into two sets of elements, while those of E. parvus act as single optical units.

In the Blake Nose sections, E. equibiramus is restricted to the upper part of the upper Albian, where it comprises as much as $48 \%$ of the total eiffellithids and $1.5 \%$ of the total nannofossil 
assemblage in abundance. Based on the age model for the Blake Nose sites, E. equibiramus existed from about 99.0 to $101.4 \mathrm{Ma}$ (a total species duration of approximately 2.4 my.).

Occurrence: upper Albian from Blake Nose (ODP Leg 171B).

Type section: Hole 1052E from Blake Nose (ODP Leg 171B)

Type Level: 1052E-45R-1, 62-65cm

Holotype: Plate 2, figures 1-2.

Eiffellithus monechiae Crux 1991, emended herein Plate 1, figures 4-6

Eiffellithus eximius (Stover) Perch-Nielsen.- HILL 1976, pl. 6, fig. 19-23, 30-33.

Eiffellithus sp. 3 PERCH-NIELSEN 1985, p. 367, fig. 35, 5-6.

Eiffellithus eximius (Stover) Perch-Nielsen. - HILL and BRALOWER

1987, pl. 1, fig. 2a-c, pl. 2, fig. 3.

Eiffellithus monechiae CRUX 1991,

Emended Diagnosis: Medium, broadly to narrowly elliptical, eiffellithid with stem base cross consisting of four arms forming an asymmetrical diagonal cross subparallel to ellipse axes, with each arm composed of two, subequal, disjunct crystal-units with clavate distal tips divided by prominent central suture.

Description: This species has a broadly to narrowly elliptical rim which is smooth to slightly serrate in outline. The outer rim is thin $(<1 \mu \mathrm{m})$ and composed of 40 to 60 steeply inclined elements. The inner rim is composed of blocky elements that are approximately $2 \mu \mathrm{m}$ wide. The rims exhibit a first order white birefringence. A small elliptical ( 3 by $4 \mu \mathrm{m}$ ) hole characterizes the middle of the central area. The central hole is spanned by an asymmetrical, diagonal cross that may have supported a small hollow stem, although no central structure was observed. The four arms of the cross lie sub-parallel to the major and minor axes of the ellipse, so that the axes of the cross and the axes of the ellipse do not differ by more than about $10^{\circ}$. Each arm is composed of two sets of elements divided by a prominent central suture. The tips of the arms are distinctly clavate.

\section{Measurements:}

Length $=5.8-7.5 \mu \mathrm{m}(\mu=6.6$, s.d. $=0.5, \mathrm{n}=30)$

Width $=3.8-5.8 \mu \mathrm{m}(\mu=4.8$, s.d. $=0.5, \mathrm{n}=30)$

Eccentricity $=1.2-1.6(\mu=1.4$, s.d. $=0.1, \mathrm{n}=30)$

Remarks: The holotype for this species, as designated by Crux (1991), is an SEM image clearly illustrating the sub-parallel relationship between the stem base arms and the principle axes of the rim ellipse. Illustrations in both Hill (1976) and Crux (1991) suggest that both authors had similar concepts for the taxon they named E. eximius and E. monechiae, respectively. The forms included in their respective concepts have been divided into three species in this paper: E. monechiae (emended herein), E. praestigium (n. sp.) and E. vonsalisiae (n. sp.).

Eiffellithus monechiae and E. praestigium are similar in size and shape, differing only by the angle formed by the axes of the cross and the axes of the ellipse. Under cross polarized light, the arms of E. monechiae always appear to be sub-parallel to the ellipse axes. The arms of E. praestigium, on the other hand, appear subparallel when the ellipse is aligned to the polarizers but appear nearly symmetrically diagonal when the ellipse is aligned at $45^{\circ}$ to the polarizers (see E. praestigium, below). The generally larger size, tapered cross arm tips, and relatively large angle between the cross axes and the ellipse axes distinguish $E$. vonsalisiae from E. monechiae.

This species differs morphologically from E. eximius in two distinct ways. The most obvious difference between these forms is in size. The length of E. monechiae averages about $6.5 \mu \mathrm{m}$, with a maximum length of $<8 \mu \mathrm{m}$. Length measurements for the type material of E. eximius are given as $10-12 \mu$ m (Stover 1966). Measurements of the holotype (Stover 1966, plate 2, fig. 15) indicate a length of $11 \mu \mathrm{m}$. The second morphological difference, cited by Crux (1991), is the narrower cycle of elements that ring the central area in E. monechiae in comparison to E. eximius. This is well expressed in the Blake Nose material. The two species also may be differentiated by their biostratigraphic ranges, as noted by Crux (1991), with E. monechiae restricted to the upper Albian and E. eximius restricted to the Turonian through upper Campanian.

Occurrence: lower upper Albian from Oklahoma and Blake Nose (ODP Leg 171B).

Type section: Locality 6264 of Hill (1976). Outcrop of Duck Creek Formation (upper Albian) on north bank of Red River approximately $4 \mathrm{~km}$ downstream (east) of the Lake Texahoma Dam, Oklahoma, USA.

Type Level: Sample HTL6302 of Hill (1976).

Holotype: Hill and Bralower 1987, plate 2, figure 3.

Eiffellithus parvus Watkins and Bergen, n. sp.

Plate 3, figures 1-6; Plate 4, figures 5-6

Etymology: (L.) parvus little.

Diagnosis: Medium eiffellithid with stem base of four trapezohedral arms forming a symmetrical diagonal cross whose outline is roughly rectangular.

Description: This species has a normally to narrowly elliptical rim which is smooth to slightly serrate in outline. The outer rim is thin $(<0.8 \mu \mathrm{m})$ and composed of steeply inclined elements, although it is generally impossible to count the elements in the light microscope. The inner rim is composed of blocky elements that fill much of the central area. The rims exhibit a first order white birefringence. A small (approximately $0.2 \mu \mathrm{m}$ ) round hole characterizes the middle of the central area. A symmetrical, diagonal cross spans the central hole. This compact species is characterized by a cross composed of four trapezohedral arms approximately $1 \mu \mathrm{m}$ in length and $<1 \mu \mathrm{m}$ in width. Each trapezohedral arm is constructed of two sets of crystallites, although these are often difficult to differentiate in the light microscope due to their small size. The individual shapes of the arms combine to give the overall outline of the cross a distinctly rectangular outline.

Measurements:

Length $=5.2-7.3 \mu \mathrm{m}(\mu=6.0$, s.d. $=0.5, \mathrm{n}=30)$

Width $=3.2-5.2 \mu \mathrm{m}(\mu=4.3$, s.d. $=0.5, \mathrm{n}=30)$

Eccentricity $=1.2-1.8(\mu=1.4$, s.d. $=0.39, \mathrm{n}=30)$

Remarks: This species differs from the closely related $E$. equibiramus by the distinctly rectangular outline of the stem base occupying the central area in E. parvus as opposed to the symmetrical, diagonal cross in E. equibiramus. Eiffellithus gorkae Reinhardt 1965 resembles E. parvus in that both taxa have a stem base that is restricted to the central area without 
touching the inner margin of the rim. The size range for $E$. gorkae, given as 5-9 $\mu \mathrm{m}$ in length by Reinhardt (1965), overlaps with $E$. parvus, but includes specimens larger than any yet observed for E. parvus. More importantly, the stratigraphic ranges of these two species are incompatible, as E. parvus existed during the late Albian and earliest Cenomanian, while E. gorkae was restricted to the Campanian-Maastrichtian (Perch-Nielsen 1985). Given this discrepancy in biostratigraphic ranges, it appears likely that E. gorkae is a morphologically iterative form.

The evidence from the Blake Nose sections, considered in the context of the proposed age model, suggests that this species lived from approximately 100.7 to $98.9 \mathrm{Ma}$ (a total species duration of 1.8 m.y.) During this interval, it comprised as much as $45 \%$ of the total eiffellithids and $2.7 \%$ of the total assemblage.

Occurrence: upper Albian from Blake Nose (ODP Leg 171B).

Type section: Hole 1052E from Blake Nose (ODP Leg 171B)

Type Level: 1052E-51R-2, 3-6cm; upper Albian.

Holotype: Plate 3, figures 1-2.

Eiffellithus praestigium Watkins and Bergen, n. sp. Plate 1, figures 7-12

Eiffellithus eximius (Stover) Perch-Nielsen. - HILL 1976, pl. 6, fig. 24-29.

Eiffellithus sp. 1 PERCH-NIELSEN 1985, p. 367, fig. 35, 5-6.

Eiffellithus eximius (Stover) Perch-Nielsen. - HILL and BRALOWER 1987, pl. 1, fig. 4a-c.

Etymology: (L.) praestigium illusion, trick, deception.

Diagnosis: Medium eiffellithid with stem base of four struts forming an asymmetrical cross lying close to, but not aligned with, principal axes of the base, with each strut composed of two sets of elements with clavate to blunt distal tips divided by a central suture.

Description: This species has a broadly to narrowly elliptical rim which is smooth to slightly serrate in outline. The outer rim is thin $(<1 \mu \mathrm{m})$ and composed of 40 to 60 steeply inclined elements. The inner rim is composed of blocky elements that are approximately $1-2 \mu \mathrm{m}$ wide. The rims exhibit a first order white birefringence. A small (approximately 3 by $4 \mu \mathrm{m}$ ) elliptical hole characterizes the middle of the central area. The central hole is spanned by an asymmetrical, diagonal cross that might have supported a small hollow stem, although no central structure has been observed. The four arms of the cross lie obliquely to the major and minor axes of the ellipse, so that the axes of the cross and the axes of the ellipse are displaced by more than about $10^{\circ}$ but less than about $20^{\circ}$. Each arm is composed of two sets of elements divided by a prominent central suture. The tips of the arms are distinctly clavate.

\section{Measurements:}

Length $=5.3-7.3 \mu \mathrm{m}(\mu=6.3$, s.d. $=0.5, \mathrm{n}=30)$

Width $=3.5-5.6 \mu \mathrm{m}(\mu=4.6$, s.d. $=0.5, \mathrm{n}=30)$

Eccentricity $=1.18-1.53(\mu=1.4$, s.d. $=0.1, \mathrm{n}=30)$

Remarks: This species is an intermediate form between $E$. monechiae and E. vonsalisiae. The most characteristic feature of this relatively small eiffellithid is the "trick" that it exhibits under cross polarized light. The two sets of elements in each arm do not exhibit simultaneous extinction under crossed polarizers, but alternately go extinct as the orientation of the crossed polarizers changes. In one orientation, the birefringent alternate sets of elements make the cross appear to be sub-parallel to the principal axes of the ellipse (text-fig 10). In the other orientation, the other four sets of elements are birefringent, making the cross appear to be nearly diagonal to the principal axes (text-fig. 10). The arms closest to the minor axes of the ellipse exhibit this phenomenon most strongly, which appear nearly aligned with the ellipse minor axis in one orientation and strongly divergent from it in another.

Occurrence: upper Albian from Oklahoma and Blake Nose (ODP Leg 171B).

Type section: Hole 1052E from Blake Nose (ODP Leg 171B)

Type Level: 1052E-58R-5, 24-28cm (681.44 mbsf); lower upper Albian.

Holotype: Plate 1, figures 10-12

Eiffellithus vonsalisiae Watkins and Bergen, n. sp. Plate 2, figures 7-9

Eiffellithus eximius (Stover) Perch-Nielsen HILL and BRALOWER 1987, pl. 1, fig. 5a-c.

Etymology: in honor of Prof. Katarina von Salis

Diagnosis: Medium to large eiffellithid with stem base of four arms forming an asymmetrical cross not aligned to either principal axes of the base, with each arm composed of two sets of elements with blunt to pointed distal tips divided by central suture.

Description: This species has a broadly to normally elliptical rim which is smooth to slightly serrate in outline. The outer rim is thin (approximately $1 \mu \mathrm{m}$ ) and composed of 35 to 60 steeply inclined elements. The inner rim is composed of blocky elements that are approximately $2 \mu \mathrm{m}$ wide. The rims exhibit a first

PLATE 1

Bar scale $=10 \mu \mathrm{m}$. Figures 2, 6, 9, and 12 are in phase contrast illumination, the others are cross-polarized light.

1-3 Vekshinella angusta; figures 1-2, 1052E-44R-5, $18-19 \mathrm{~cm}$, figure $3,1052 \mathrm{E}-58 \mathrm{R}-5,24-28 \mathrm{~cm}$.

46 Eiffellithus monechiae Crux 1991, 1050C-31R-6, $99-100 \mathrm{~cm}$.
7-12 Eiffellithus praestigium n. sp., 1052E-58R-3, 40-42cm; figures 10-12, (holotype specimen), 1052E-58R-5, 24-28cm. 

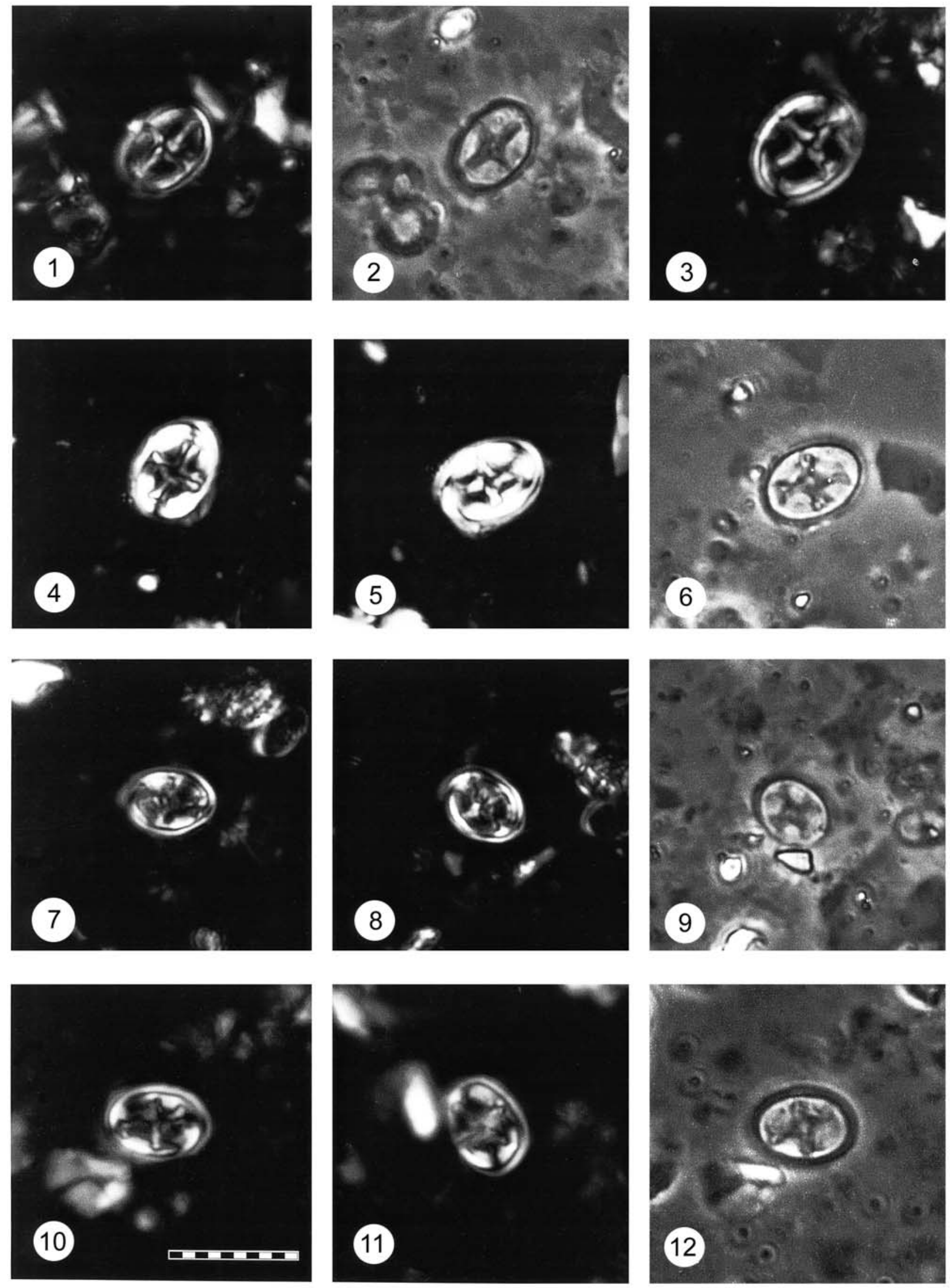
order white birefringence, although the largest specimens have a markedly yellow overtone. A small (approximately 3 by $2 \mu \mathrm{m}$ ) elliptical hole characterizes the middle of the central area. The central hole is spanned by an asymmetrical, diagonal cross that might have supported a small hollow stem, although no central structure has been observed. The four arms of the cross lie obliquely to the major and minor axes of the ellipse, so that the axes of the cross and the axes of the ellipse are displaced by more than about $20^{\circ}$ but less than about $35^{\circ}$. Each arm is composed to two sets of elements divided by a central suture that is usually only faintly evident. The arms taper distally and the tips of the arms are distinctly pointed. Numerous specimens were observed with a small but distinct offset of the cross arms nearest to the minor axis.

\section{Measurements:}

Length $=6.4-9.0 \mu \mathrm{m}(\mu=7.7$, s.d. $=0.8, \mathrm{n}=30)$

Width $=4.4-6.9 \mu \mathrm{m}(\mu=5.7$, s.d. $=0.6, \mathrm{n}=30)$

Eccentricity $=1.3-1.5(\mu=1.4$, s.d. $=0.1, n=30)$

Remarks: This species differs from E. praestigium (its presumed ancestral form) by its somewhat larger size and by the greater divergence of the cross axes from the ellipse axes. The alignment of the cross arms at about $10-20^{\circ}$ to the ellipse axes in E. praestigium results in a peculiar optical illusion such that when the ellipse is aligned with the polarizers, the cross axes appear subparallel to the ellipse axes. This is especially true of those arms near the minor ellipse axis. This is never true in $E$. vonsalisiae, as the cross arms always appear divergent from the ellipse axes regardless of the orientation of the coccolith.

This species differs from E. turriseiffelii by the clearly symmetrical, diagonal cross of the latter as opposed to the asymmetrical diagonal nature of the cross in E. vonsalisiae.

In the Leg $171 \mathrm{~B}$, E. vonsalisiae is restricted to the uppermost Albian, where it comprises as much as $32 \%$ of the total eiffellithids and $0.7 \%$ of the total assemblage in abundance. Based on the age model for the Blake Nose sites, E. vonsalisiae existed from about 99.0 to $101.1 \mathrm{Ma}$ (a total species duration of approximately 2.1 my.).

The transitional nature of its first and last appearance, coupled with its tendency toward rarity at the top and base of its stratigraphic range, suggests that E. vonsalisiae would not make a reliable biostratigraphic indicator. In addition, morphologically similar forms are known from the Turonian and from the Campanian-Maastrichtian. This suggests that this simple mor- phological variant of E. turriseiffelii may appear in an iterative fashion more than once during the Late Cretaceous.

Occurrence: upper Albian.

Type section: Hole 1052E from Blake Nose (ODP Leg 171B)

Type Level: 1052E-42R-5, 63-66cm.

Holotype: Plate 1, figures 7-9.

The following Albian-Cenomanian taxa have been attributed to the genus Eiffellithus, but have no direct phylogenetic link to the true Eiffellithus lineage. They have been left in the genus pending a general reconsideration of the loxolith genera.

\section{Eiffellithus? hancockii BURNETT 1998}

Plate 3, fig. 9-12; Plate 4, figure 1

Eiffellithus? hancockii BURNETT 1998a. - BURNETT 1998b, p. 172, pl. 6.3, figs. 25a-b.

Remarks: Burnett (1998a) wisely questioned the placement of this species in the genus Eiffellithus. In the Leg 171B material, there is a clear transition between E.? hancockii and an unnamed bicyclic form assignable to Vagalapilla Bukry 1969 or Staurolithites Caratini 1963, as illustrated in Plate 3, figs. 9-12 and Plate 4, figure 1.

Occurrence: upper Albian and lowermost Cenomanian.

Eiffellithus paragogus Gartner 1993

Plate 4, figs. 2-3

Coccolithus matalosus STOVER 1966, partim, p. 137, pl. 2, fig. 1a-c; pl. 8, fig. 10; non, pl. 2, fig 2a-b.

Staurolithites matalosus (Stover 1966) Cepek and Hay 1969. - ROTH and THIERSTEIN 1972, p. 425, pl. 13, figs. 6-11.

Vagalapilla matalosa (Stover 1966) THIERSTEIN 1973, p. 139, pl. 1, figs. 12-14.

Vagalapilla matalosa (Stover 1966) Thierstein 1973. - THIERSTEIN 1976 , p. 352, pl. 3, figs. 35-36.

Eiffellithus paragogus GARTNER 1993, in Robasynski et al., p. 443, pl. 24 , figs. 6a-c.

Bownia glabra JEREMIAH 1996, p. 125, pl. 3, fig. 20.

Staurolithites glabra (Jeremiah 1996) BURNETT 1997, p. 140.

Staurolithites glaber (Jeremiah 1996) Burnett 1998. - BURNETT 1998 p. 312, pl. 6.1, fig. 26.

Staurolithites glabra (Jeremiah 1996) Burnett 1998. - BOWN 1998, p. 114, pl. 5.7, figs. 19-20.

PLATE 2

Bar scale $=10 \mu \mathrm{m}$. Figures 2, 6, and 9 are in phase contrast illumination, the others are cross-polarized light.

1-6 Eiffellithus equibiramus n. sp.; figures 1-2 (holotype specimen) from $1052 \mathrm{E}-45 \mathrm{R}-1,62-65 \mathrm{~cm}$; figure 3 (paratype) from 1052E-45R-1, 62-65cm; figures 4-6 (paratype) from 1052E-50R-2, 23-24cm.
10-12 Eiffellithus turriseiffelii (Deflandre) (Reinhardt 1965), figures $10-11$ from $1050 \mathrm{C}-23 \mathrm{R}-6,41-43 \mathrm{~cm}$ (Cenomanian); figure 12 from 1049A-17X-3, $149-150 \mathrm{~cm}$ (Maastrichtian).

7-9 Eiffellithus vonsalisiae n. sp, (holotype specimen), 1052E-42R-5, 63-66cm. 

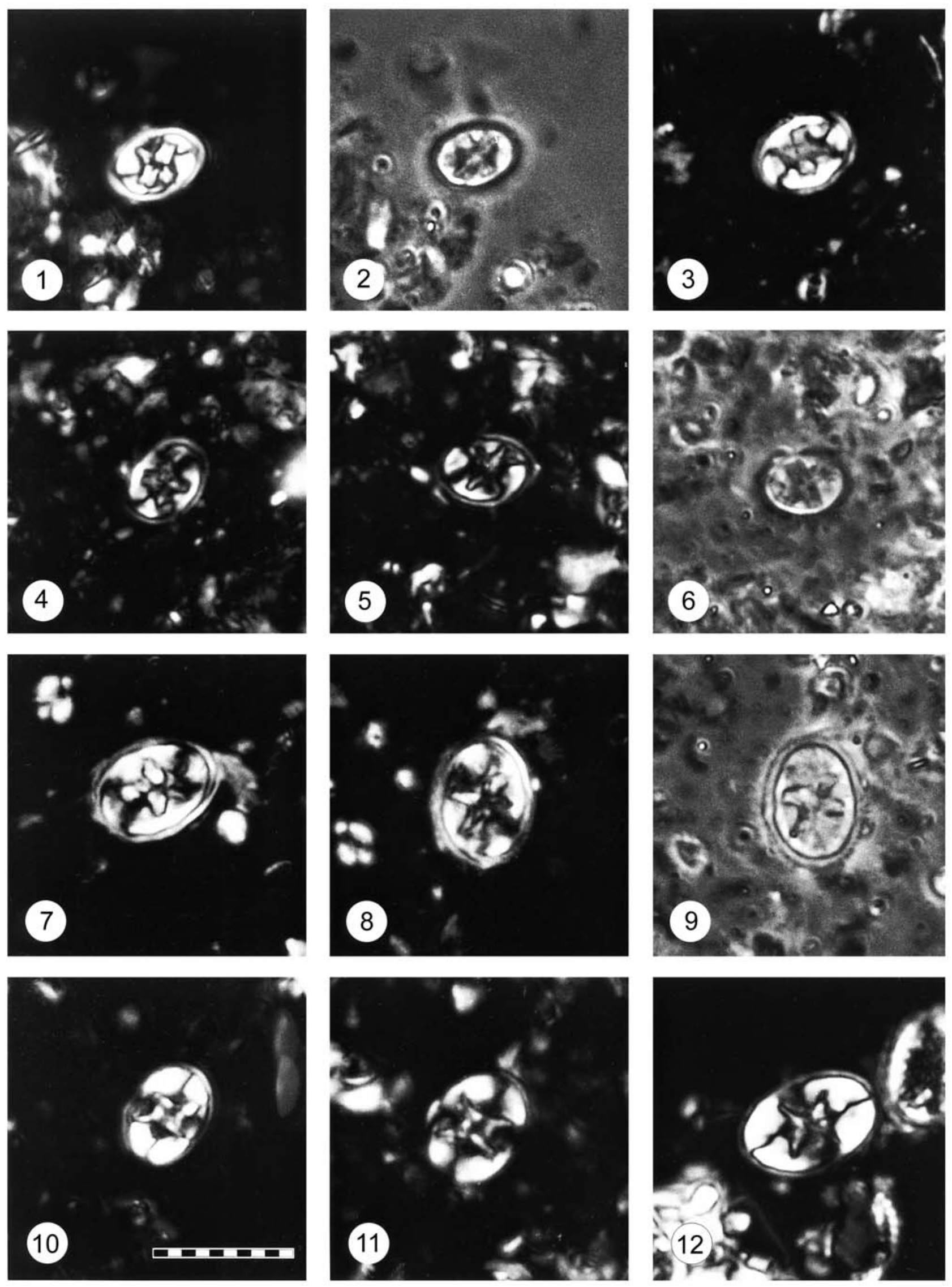
Remarks: This cosmopolitan murolith is characterized by its diamond-shaped central opening, simple axial cross, and eiffellithid-like rim. In cross-polarized light, the rim is bicyclic and displays a first order white birefringence. The inner rim cycle is broad (up to $1.5 \mu \mathrm{m}$ ) and is crossed by radial extinction lines; the outer rim cycle is narrow $(<1 \mu \mathrm{m})$. The inner rim is thicker than corresponding rims in true Eiffellithus, suggesting that this rim structure resembles Eiffellithus by morphological convergence rather than phylogenetic relationship. The stratigraphic record clearly indicates no direct descent from the older $E$. paragogus and E. monechiae (the form that gave rise to the true Eiffellithus of the Late Cretaceous).

Confusion over the name of this species was caused by the two original illustrations of Coccolithus matalosus by Stover (1966). The holotype of Coccolithus matalosus is clearly a placolith and belongs within the genus Broinsonia. The paratype specimen, however, is a murolith and subsequent authors (e.g., Thierstein 1976) have illustrated this form. Gartner (1993) described Eiffellithus paragogus from the Tunisian lower Cenomanian, and his light photomicrograph of the holotype is definitive of the species concept. Staurolithites glabra Jeremiah (1996) was also illustrated by light photomicrographs and is a junior synonym. Unfortunately, this binomial has propagated through recent literature.

Occurrence: lower Aptian to lowermost Cenomanian.

\section{REFERENCES}

BELLIER, J.-P., MOULLADE, M. R. and HUBER, B.T., 2001. Mid-Cretaceous planktonic foraminifers from Blake Nose: revised biostratigraphic framework. Proceedings of the Ocean Drilling Program, Scientific Results, 171B:1-12.

BOWN, P. R., RUTLEDGE, D. C., CRUX, J. A. and GALLAGHER, L. T., 1999. Lower Cretaceous, In: Bown, Paul R., Ed., Calcareous nannofossil biostratigraphy. Dordrecht, Netherlands: Kluwer Academic Publishers, 86-131.

BRALOWER, T. J., SLITER, W. V., ARTHUR, M. A., LECKIE, R. M., ALLARD, D. and SCHLANGER, S. O., 1993. Dysoxic/anoxic episodes in the Aptian-Albian (Early Cretaceous). In: Pringle, Malcolm S., Sager, William W., Sliter, William V., and Stein, Seth, Eds., The Mesozoic Pacific; geology, tectonics, and volcanism. Geophysical Monograph. 73: 5-37.

BRALOWER, T.J., FULLAGAR, P.D., PAULL, C.K., DWYER, G.S., LECKIE, R.M., 1997. Mid-Cretaceous strontium-isotope stratigraphy of deep-sea sections. Geological Society of America Bulletin, 109: 1421-1442.
CHANG, Y.-M., 1967. Accuracy of fossil percentage estimation. Journal of Paleontology, 41:500-502.

CRUX, J. A., 1991. Albian calcareous nannofossils from the Gault Clay of Munday's Hill (Bedfordshire, England). Journal of Micropalaeontology, 10:203-222.

HIBBERD, D. J., 1976. The ultrastructure and taxonomy of the Chrysophyceae and Prymnesiophyceae (Haptophyceae): a survey with some new observations on the ultrastructure of the Chrysophyceae. Botanical Journal of the Linnaen Society, 72:55-80.

HILL, M. E., III, 1975. Selective dissolution of mid-Cretaceous (Cenomanian) calcareous nannofossils. Micropaleontology, 21:227-235.

1976. Lower Cretaceous calcareous nannofossils from Texas and Oklahoma. Palaeontographica, B, 156:103-179.

HILL, M. E., III and BRALOWER, T. J., 1985. The evolution of Eiffellithus eximius; a pre-Cenomanian nannofossil event. In: van Heck, S. E., Ed., Proceedings of the International Nannoplankton Association. Shell UK Expro, London, United Kingdom. INA Newsletter. 7:66.

HILL, M. E., III and BRALOWER, T. J., 1987. Early evolution, stratigraphy and taxonomy of Eiffellithus eximius and closely-related species. In: Stradner, H., Perch Nielsen, K, Eds., International Nannoplankton Association; Proceedings. Geolischen Bundesanst., Vienna, Austria. Abhandlungen der Geologischen Bundesanstalt. 39.

HOFFMANN, N., 1970. Taxonomische Untersuchungen an Coccolithineen aus der Kreide Norddeutschlands anhand elektronenmikroskopischer Aufnahmen. Hercynia, 7:163-198.

MANIVIT, H., PERCH, N. K., PRINS, B. and VERBEEK, J. W., 1977. Mid Cretaceous calcareous nannofossil biostratigraphy. Koninkl. Nederlandse Akad. Wetensch. Proc., Ser. B, 80:169-181.

NORRIS, R. D., KROON, D. and KLAUS, A., 1998. Proceedings of the Ocean Drilling Program, Initial Reports, College Station, TX, Ocean Drilling Program, 171B.

PERCH-NIELSEN, K., 1979. Calcareous nannofossils from the Cretaceous between the North Sea and the Mediterranean. In: Wiedmann, J., Ed., Aspekte der Kreide Europas. International Union of Geological Science, Series A:223-272.

1985. Mesozoic calcareous nannofossils. In: Bolli, H, M., Saunders, J.B., Perch-Nielsen, K., Eds., Plankton Stratigraphy. Cambridge: Cambridge University Press.

PLATE 3

Figures 3 and 5 are in phase contrast illumination, figure 6 is plain light, the others are cross-polarized light.

1-6 Eiffellithus parvus $\mathrm{n}$. sp.; figures 1-2 (holotype specimen) from 1052E-51R-2, 3-6cm; figure 3 (paratype) from 1050C-27R-3, 131-132cm; figures 4-6 (paratype) from 1052E-49R-5, 89-92cm.
7-8 Eiffellithus collis (Hoffmann 1970) from 1052E42R-3, 63-64cm.

9-12 forms transitional from Vagalapilla sp. indet. and Eiffellithus? hancockii. 

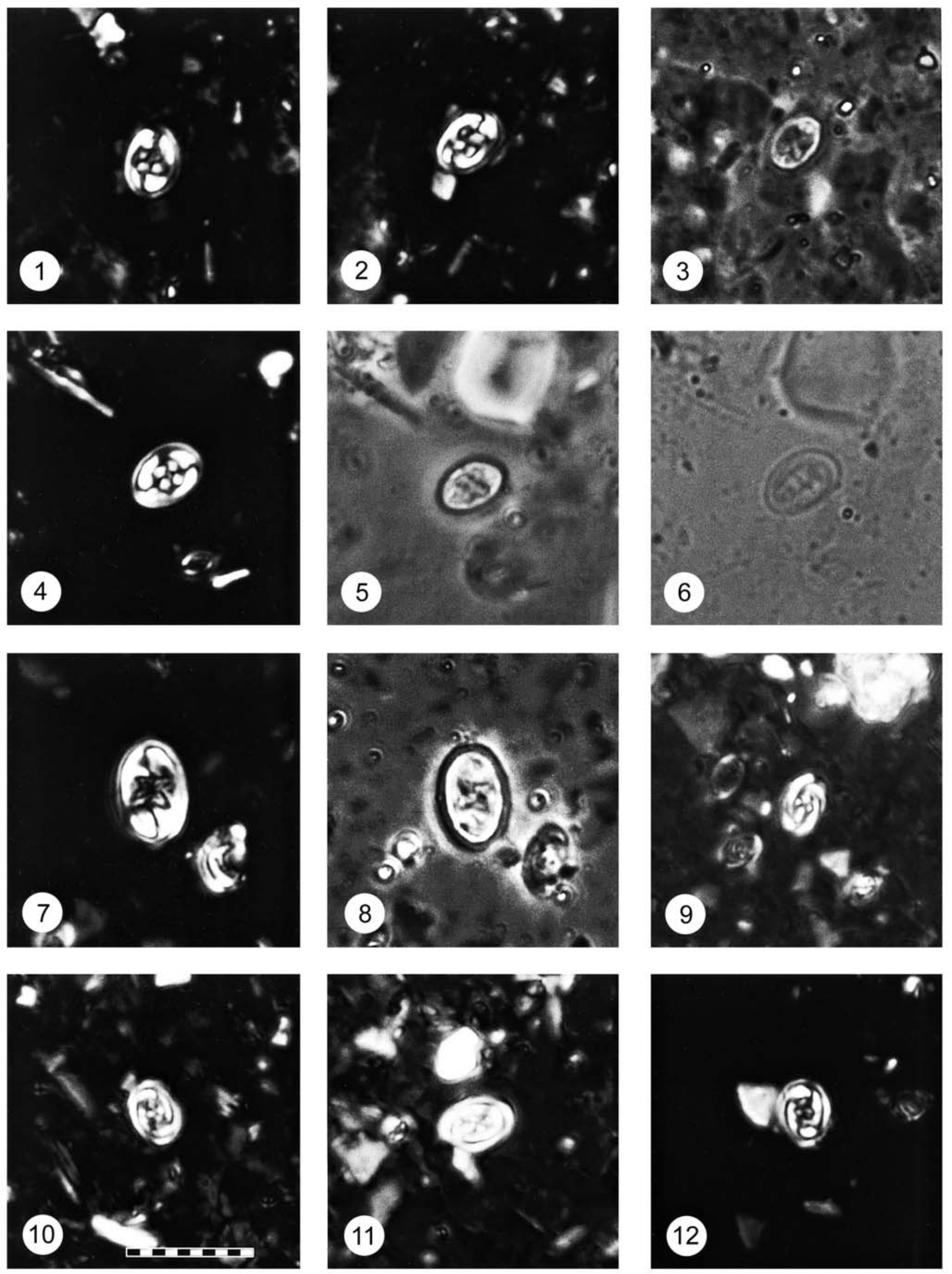
REINHARDT, P., 1965. Neue familien fur fossile kalkflagellaten (Coccolithophoriden, Coccolithineen). Monatsberichte der Deutschen Akademie der Wissenschaften zu Berlin, 7:30-40

ROBASZYNSKI, F., HARDENBOL, J., CARON, M., AMEDRO, F., DUPUIS, C., GONZALEZ-DONOSO, J., LINARES, D., and GARTNER, S., 1993. Sequence stratigraphy in a distal environment; the Cenomanian of the Kalaat Senan region (central Tunisia). Bulletin des Centres de Recherches Exploration-Production Elf-Aquitaine. 17: 395-433.

ROOD, A. P., HAY, W. W. and BARNARD, T., 1971. Electron microscope studies of Oxford Clay coccoliths. Eclogae Geologicae Helvetiae, 64:245-271.

SISSINGH, W., 1977. Biostratigraphy of Cretaceous calcareous nannoplankton. Geologie Mijnbouw, 56:37-65.

STOVER, L. E., 1966. Cretaceous coccoliths and associated nannofossils from France and the Netherlands. Micropaleontology., 12:133-166

STRADNER, H., 1964. New contributions to Mesozoic stratigraphy by means of nannofossils [with discussion]. World Petroleum Congress, 6th, Frankfurt am Main, Pr, sec:1.
THIERSTEIN, H. R., 1971. Tentative Lower Cretaceous Calcareous Nannoplankton Zonation. Eclogae Geologicae Helvetiae, 64:459-487.

1976. Mesozoic calcareous nannoplankton biostratigraphy of marine sediments. Marine Micropaleontology, 1:325-362

, 1980. Selective dissolution of Late Cretaceous and earliest Tertiary calcareous nannofossils; experimental evidence. Cretaceous Research, 1:165-176

VAROL, O. and GIRGIS, M., 1994. New taxa and taxonomy of some Jurassic to Cretaceous calcareous nannofossils. Neues Jahrbuch für Geologie und Palaontologie, Abhandlungen, 192:221-253

VERBEEK, J. W., 1977. Calcareous nannoplankton biostratigraphy of Middle and Upper Cretaceous deposits in Tunisia, southern Spain and France. Utrecht Micropalaeontological Bulletin, 16:1-157

WILSON, P., A. and NORRIS, R., D., 2001. Warm tropical ocean surface and global anoxia during the mid-Cretaceous period. Nature, 412:425-429

Manuscript received May 1, 2002

Manuscript accepted July 10, 2003

\section{PLATE 4}

Figures 1 and 2 are cross-polarized light, figure 3 is in phase contrast illumination. The bar scale in figure 1 represents $10 \mu \mathrm{m}$ in length and applies for figures 1-3. Figures 4-7 are scanning electron micrographs, bar scale in each is $1 \mu \mathrm{m}$.

1 Eiffellithus? hancockii, 1052E-39R-1, 95-98cm.

2-3 Eiffellithus paragogus, 1052E-43R-6, 127-130cm.

4 Eiffellithus equibiramus (paratype), 1052E-49R-5, 89-92.
5-6 Eiffellithus parvus (paratypes), 1052E-46R-5, $7-10 \mathrm{~cm}$.

7 Eiffellithus turriseiffelii ( $<8 \mu \mathrm{m}$ morphotype), 1052E-46R-5, 7-10cm. 

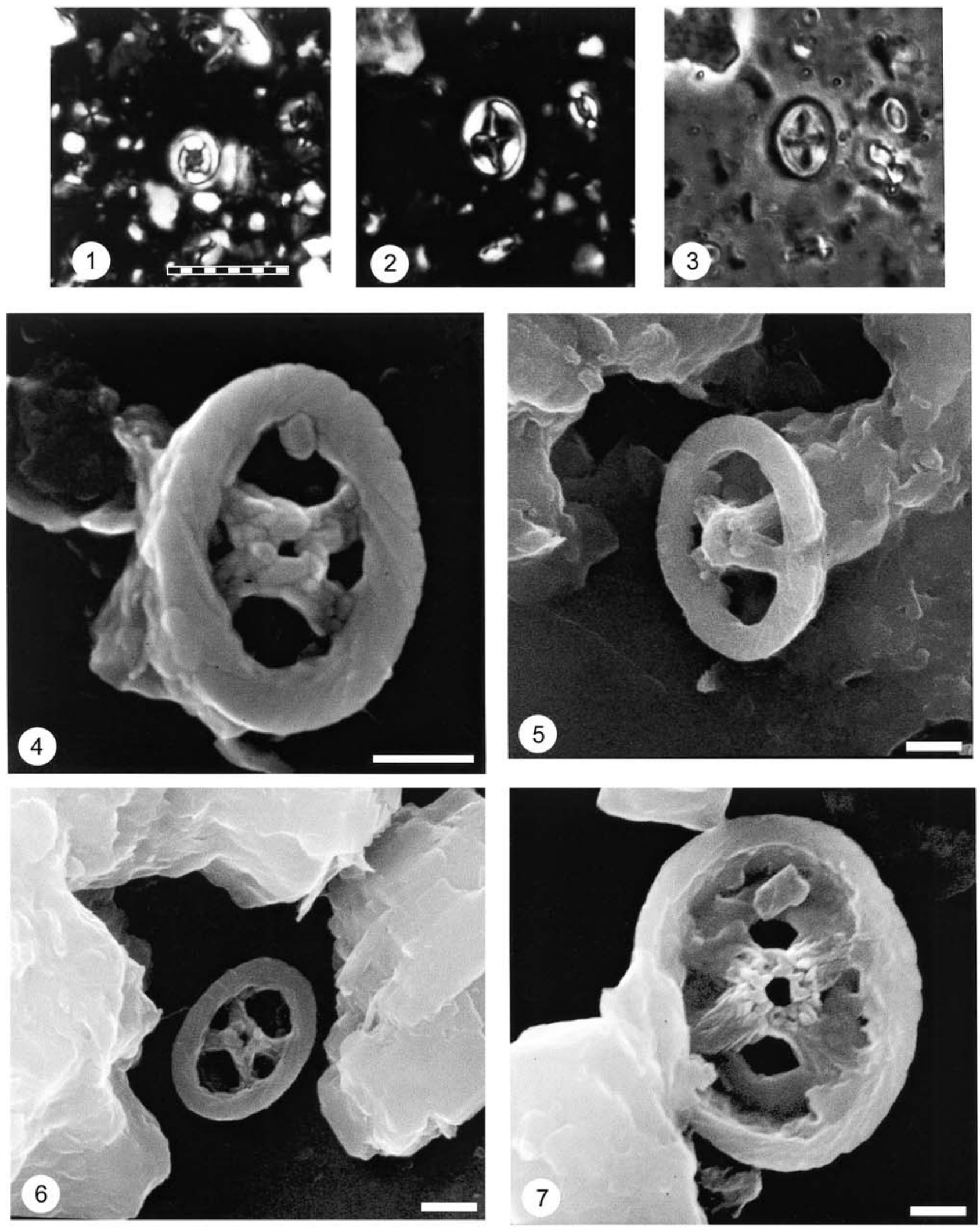
